\title{
Oxidative stress and antioxidative responses in plant-virus interactions
}

\author{
José Antonio Hernández a, ${ }^{\text {* }}$, Gábor Gullner ${ }^{\mathrm{b}}$, María José Clemente-Moreno ${ }^{\mathrm{c}}$, \\ András Künstler ${ }^{\mathrm{b}}$, Csilla Juhász ${ }^{\mathrm{b}}$, Pedro Díaz-Vivancos ${ }^{\mathrm{a}}$, Lóránt Király ${ }^{\mathrm{b}}$ \\ ${ }^{a}$ Group of Fruit Trees Biotechnology, Dept. Plant Breeding, CEBAS-CSIC, Campus Universitario de Espinardo, Murcia, P.O. Box 164, E-30100, Spain \\ ${ }^{\mathrm{b}}$ Plant Protection Institute, Centre for Agricultural Research, Hungarian Academy of Sciences, H-1022, Budapest, Herman Ottó Str. 15, Hungary \\ ${ }^{\mathrm{c}}$ Biology of Plants Under Mediterranean Conditions Group, Faculty of Biology, University of the Balearic Islands, Valldemosa Road, Palma de Mallorca, \\ E-07122, Spain
}

\section{A R T I C L E I N F O}

\section{Article history:}

Received 1 June 2015

Received in revised form

7 September 2015

Accepted 10 September 2015

Available online $\mathrm{xxx}$

\section{Keywords:}

Antioxidative metabolism

Compatible interactions

Incompatible interactions

Oxidative stress

Reactive oxygen species

\begin{abstract}
A B S T R A C T
During plant-virus interactions, defence responses are linked to the accumulation of reactive oxygen species (ROS). Importantly, ROS play a dual role by (1) eliciting pathogen restriction and often localized death of host plant cells at infection sites and (2) as a diffusible signal that induces antioxidant and pathogenesis-related defence responses in adjacent plant cells. The outcome of these defences largely depends on the speed of host responses including early ROS accumulation at virus infection sites. Rapid host reactions may result in early virus elimination without any oxidative stress (i.e. a symptomless, extreme resistance). A slower host response allows a certain degree of virus replication and movement resulting in oxidative stress and programmed death of affected plant cells before conferring pathogen arrest (hypersensitive response, HR). On the other hand, delayed host attempts to elicit virus resistance result in an imbalance of antioxidative metabolism and massively stressed systemic plant tissues (e.g. systemic chlorotic or necrotic symptoms). The final consequence of these processes is a partial or almost complete loss of control over virus invasion (compatible infections).
\end{abstract}

๑) 2015 Elsevier Ltd. All rights reserved.

\section{Introduction}

Plants constantly attempt to resist pathogenic invaders by eliciting various defence responses governed by different mechanisms (e.g. accumulation of antimicrobial compounds, cell wall reinforcement, localized cell and tissue death, HR, ROS) [see e.g. $[55,77,84,141,146]]$. Often these plant defence responses are elicited too late for effective pathogen limitation to occur, resulting in a stressed plant and a compatible infection (i.e. disease). This is particularly true for viral infections, since viruses - as opposed to bacteria and fungi - enter plant cells and are intimately associated with the cytoplasm and cellular organelles during viral pathogenesis even before the host plant may elicit defence responses.

Importantly, many of the above-mentioned plant defence responses (antimicrobial compounds, cell wall reinforcement, HR) against pathogens including viruses are governed, at least in part, by a controlled accumulation of reactive oxygen species (ROS)

\footnotetext{
* Corresponding author.

E-mail address: jahernan@cebas.csic.es (J.A. Hernández).
}

$[12,38,93,135,146,147]$. In fact, ROS, especially hydrogen peroxide $\left(\mathrm{H}_{2} \mathrm{O}_{2}\right)$, seem to play a dual role by eliciting localized death/limitation of host plant cells and pathogens and as a diffusible signal for the induction of antioxidant and pathogenesis-related genes in adjacent plant tissues, as initially demonstrated for bacterial and fungal infections $[22,93,152]$. However, this dual role of ROS in plant defence - i.e. localized pathogen inhibition/oxidative stress and antioxidant/defence signalling - has been also demonstrated in virus-infected plants [see e.g. $[1,11,36,63,71,91]]$. The purpose of this review is to discuss how the dual role of ROS is differentially manifested during incompatible and compatible virus infections of plants. In particular, we attempted to recapitulate our knowledge about the oxidative stress elicited by pathogenic viruses, the resulting antioxidative responses of host plants and the roles of these processes in establishing successful resistance to virus infections.

\section{ROS and oxidative stress in plants - general roles in defence to pathogenic infections}

The accumulation of ROS and the resulting oxidative stress in 
plants elicited by pathogenic microorganisms, mostly bacterial and fungal pathogens, has been the subject of several outstanding reviews $[12,14,89,90,146,147]$. Therefore, we intend to provide only a brief summary here on the general roles of ROS and oxidative stress in plant defence responses to pathogenic infections. The formation of ROS (superoxide anion, hydrogen peroxide, hydroxyl radical and singlet oxygen) from molecular oxygen is a regular process in aerobic organisms. Molecular oxygen is relatively inert but it can be activated either by enzymatic reduction to superoxide anion $\left(\mathrm{O}_{2}{ }^{--}\right)$ and hydrogen peroxide $\left(\mathrm{H}_{2} \mathrm{O}_{2}\right)$ or by spin conversion that produces singlet oxygen $\left({ }^{1} \mathrm{O}_{2}\right)[12,88,89]$. Superoxide and $\mathrm{H}_{2} \mathrm{O}_{2}$ are normal plant metabolites although they are toxic at high concentrations. Their formation and decomposition are mostly enzymatically regulated. On the other hand, the highly toxic and reactive hydroxyl radical ( $\mathrm{OH}$ ) and ${ }^{1} \mathrm{O}_{2}$ are harnessed in plant cells by non-enzymatic mechanisms [125,148].

Infection of plants by pathogenic microorganisms often results in oxidative stress (also called oxidative burst), i.e. the rapid and massive accumulation of ROS in infected tissues. In bacterium- and fungus-inoculated cells the accumulation of ROS occurs in two subsequent phases. The initial, very rapid but weak and transient rise in ROS levels (phase I) is unspecific, it can be detected in both incompatible and compatible plant-pathogen interactions. The second, slower but strong and sustained phase of oxidative stress (phase II) takes place only in incompatible plant-pathogen interactions and it is usually associated with resistance $[12,58,89,147]$. The sources of ROS production and the type of ROS produced may markedly differ between the two consecutive phases of oxidative stress. Experiments with fluorescently tagged tobacco mosaic virus (TMV) suggested that virus-induced oxidative stress and resistance that results in a HR is also a two-phase process with an early stage culminating in rapid cell collapse and tissue necrosis at infection foci followed by a more extended period during which the remaining infected cells are eliminated [151].

The accumulating ROS have a dual role in infected plants. ROS may promote programmed cell death (PCD) of infected plant cells and also the death/limitation of invading pathogens due to their high toxicity. On the other hand, ROS play crucial roles also as signalling compounds during the activation of host defence responses, including the induction of antioxidants, in healthy cells adjacent to infected ones [34,93]. In fact, the up-regulation of antioxidants is the most obvious marker of oxidative stress [67]. Antioxidant responses are governed in part by non-enzymatic scavengers and low molecular weight compounds, such as ascorbic acid (ASC), reduced glutathione (GSH) and phenolic compounds. Enzymatic ROS scavengers include antioxidant enzymes like superoxide dismutase, catalase and enzymes related to the ascorbate-glutathione cycle (e.g. ascorbate peroxidase, dehydroascorbate reductase, monodehydroascorbate reductase, glutathione reductase and glutathione peroxidase) [see e.g. $[8,9,49,74,116,156]]$.

Superoxide anion and $\mathrm{H}_{2} \mathrm{O}_{2}$ can be produced in different plant cell compartments during electron transport processes and by a large number of enzymes including plasma membrane-bound NADPH-oxidase isoenzymes, various oxidases and cell wall-bound peroxidases [117,128,147,155]. Particular attention has been paid to superoxide-producing NADPH-oxidases due to their resemblance to mammalian neutrophil plasma membrane NADPHoxidases [131]. These enzymes are activated during the respiratory burst observed at phagocytosis and the increased production of $\mathrm{O}_{2}{ }^{--}$contributes to the elimination of engulfed pathogenic microorganisms [110,114,133]. Mammalian NADPH-oxidases are tightly controlled multicomponent enzymes made up of membrane-associated catalytic proteins and cytosolic regulatory components that must assemble to form the active oxidase [60].
Plasma membrane-localized NADPH oxidases (also called respiratory burst oxidase homologues, RBOHs) are a major source of ROS production also in plants, but their structure and regulation are markedly different from mammalian homologues [58,89,109]. Plant NADPH-oxidase proteins have a large hydrophilic N-terminal domain that is absent in mammalian enzymes. This domain contains two calcium binding motifs [79]. Sagi and Fluhr [132] demonstrated that a tobacco NADPH-oxidase was stimulated by $\mathrm{Ca}^{2+}$ in the absence of other cytosolic components in contrast to mammalian orthologues. Recent studies identified NADPHoxidases as key signalling nodes in plants integrating calcium signalling and protein phosphorylation with ROS production $[41,54,143]$.

\section{Oxidative stress during incompatible plant-virus interactions}

\subsection{Plant NADPH oxidase-driven, plasma membrane-related ROS generation and virus resistance}

The first evidence for the role of ROS and oxidative stress in virus resistance of plant hosts (i.e. incompatible virus infections) came from the pioneering discovery of Doke and Ohashi [38] who demonstrated the involvement of an early, specific oxidative burst in the resistance of tobacco (Nicotiana tabacum) to TMV. NADPHand $\mathrm{Ca}^{2+}$-dependent $\mathrm{O}_{2}{ }^{--}$generation occurred in membrane-rich fractions only during incompatible tobacco/TMV interactions governed by the resistance gene $N$, indicating the role of the strong, persistent phase II of the oxidative burst in virus resistance. In fact, these results suggested that $\mathrm{O}_{2}{ }^{-}$- was produced by membrane bound NADPH oxidases [38] (Fig. 1). Interestingly, it was shown that the resistance-independent phase I of the ROS burst elicited by TMV is also a NADPH oxidase-driven reaction requiring a certain secondary structure of the TMV coat protein [3]. These processes imply an early perception of virus-encoded factors by host receptors in resistant plants. In fact, the protein product of the resistance gene $N$ specifically recognizes the $50 \mathrm{kDa}$ helicase domain of the TMV replicase (p50) in the cytoplasm mediated by a chloroplastic sulfurtransferase, NRIP1 (N receptor-interacting protein 1) [16,20]. Although, as mentioned above, the phase I of the oxidative burst is not correlated with pathogen resistance it could play a role as a priming mechanism for phase II and downstream plant defence signalling processes [12]. For example, rapid changes in the alternative splicing patterns of $N$ resistance gene transcripts were detected within three hours of TMV infection that well precedes phase II of the ROS burst [37].

A role of NADPH oxidase-dependent superoxide (ROS) production in $N$ gene-mediated resistance to TMV was also suggested by the work of Moeder et al. [109], who studied the influence of an essential NADPH oxidase-regulator, the small GTP-binding protein Rac [132], on TMV resistance of tobacco (cv. Xanthi NN). This type of virus resistance is typically manifested as a HR, i.e. a localized, programmed cell death associated with pathogen restriction at infection sites resulting in the formation of macroscopic necrotic lesions [56,57,84]. Moeder et al. [109] have found that in TMVinoculated, $N$ gene-expressing tobacco the overexpression of a dominant negative form of the rice OsRac1 gene significantly reduces HR-associated production of ROS $\left(\mathrm{O}_{2}{ }^{-}\right.$and $\left.\mathrm{H}_{2} \mathrm{O}_{2}\right)$. In comparison to wild-type Xanthi $N N$ tobacco, transgenic DN-OsRac1 plants exhibited a delay in HR formation, produced smaller TMVinduced lesions associated with a lower rate of lipid peroxidation (an oxidative stress marker) and failed to activate expression of antioxidant genes. Although TMV titres were not assayed in virusinfected DN-OsRac1 plants, these results indeed suggest that a tight regulation of NADPH oxidase-driven superoxide production is a 


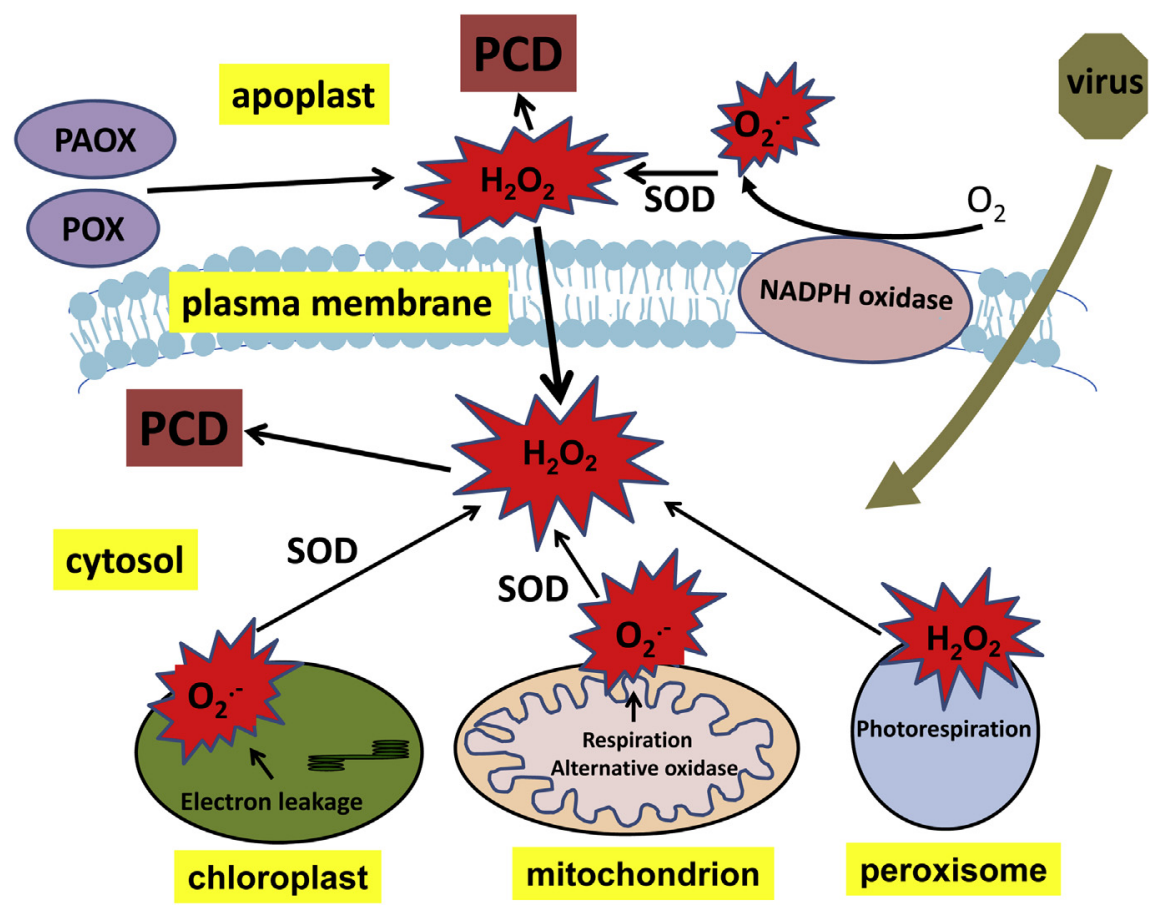

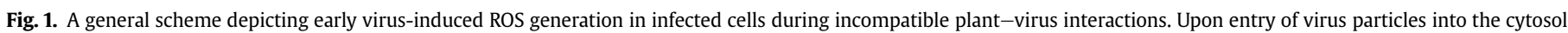

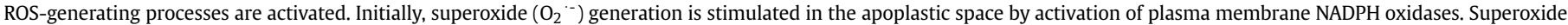

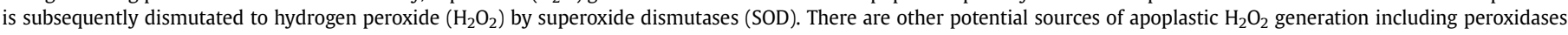

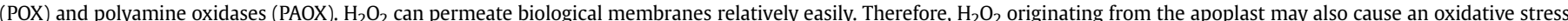

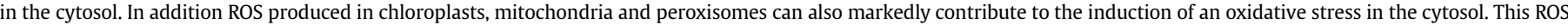

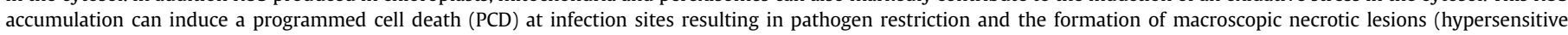
response, HR).

pivotal component of virus resistance [109]. In fact, we have shown that not only HR-type resistance to TMV but NADPH oxidasedependent $\mathrm{O}_{2} \cdot-$-generation is also suppressed in tobacco plants carrying the resistance gene $N$ and exposed to higher $\left(30{ }^{\circ} \mathrm{C}\right.$ ) temperatures [80]. Suppression of superoxide and TMV resistance at $30{ }^{\circ} \mathrm{C}$ was correlated with a down-regulation of both NADPH oxidase activity and expression of the tobacco NADPH oxidase gene NtRBOHD. Taken together, NADPH oxidase-dependent superoxidegeneration seems to be instrumental in the development of resistance to viruses, similarly as shown for other (bacterial, oomycete, fungal) pathogens [see e.g. [90,101]] (Fig. 1).

\subsection{Plant intracellular ROS - potential roles in limiting virus infections}

Plant viruses - as opposed to bacteria and fungi - can enter the intracellular space of plant cells where they are intimately associated with the cytoplasm and cellular organelles during viral pathogenesis (i.e. they are obligate biotrophic pathogens). Therefore, it seems logical that resistance responses to virus infections should be profoundly influenced by ROS-related biochemical processes that occur within plant cells at different subcellular sites (organelles).

Plant mitochondria, the organelles responsible for respiration, may play an important role in host defence to pathogens like viruses. A pronounced increase in the respiratory rate of a host can be a marker of disease resistance $[56,68,139]$ and references within]. In mitochondria, electrons produced by oxidation processes flow through either the cytochrome or the alternative respiratory pathways. The primary function of alternative oxidases (AOX) located in the mitochondrial inner membrane is to prevent overreduction of the cytochrome pathway and the resulting accumulation of ROS during abiotic stresses and pathogen attack
[24,105,127] (Fig. 1). Recently, it has been shown that salicylic acid, a central regulator of plant disease resistance, may inhibit the cytochrome pathway by binding to alpha-ketoglutarate dehydrogenase E2 ( $\alpha-\mathrm{kGDH}$ E2), a rate limiting enzyme controlling efficient mitochondrial electron transport. This results in limiting TMV accumulation, a process that requires expression of the AOX1a gene [95]. The authors suggest that inhibition of $\alpha-\mathrm{kGDH}$ E2 could result in elevated ROS generation that activates AOX and virus resistance. Accordingly, Nicotiana sylvestris mutants with elevated AOX protein levels display a higher degree of resistance to TMV [45]. Furthermore, AOX transcript and protein levels increase in tobacco that displays HR to TMV, but not during compatible tobacco-TMV interactions $[24,25,80]$. Therefore, increased production of mitochondrial ROS and its control by AOX could be a key factor of plant resistance to pathogens like viruses that could be in close contact with mitochondria and therefore might be directly inhibited by high concentrations of e.g. mitochondrial ROS during HR-type resistance. In fact, loss of HR-type resistance to TMV in tobacco at high temperatures $\left(30^{\circ} \mathrm{C}\right)$ is associated with a down-regulation of AOX mRNA expression and $\mathrm{O}_{2}{ }^{--}$levels suggesting that mitochondrial AOX indeed contributes to the regulation of ROS levels during HR in order to prevent excessive plant cell death [80].

In photosynthetic organisms, chloroplasts transform light into reducing power resulting in $\mathrm{CO}_{2}$ fixation and carbohydrate production during photosynthesis. Excess reducing power following environmental and/or pathogen stress may accelerate electron leakage from the photosynthetic electron transport chain of chloroplast thylakoid membranes including photosystems (PS) I and II leading to ROS generation and oxidative damage [see e.g. [34] and references within]. In fact, the plant defence-related oxidative burst occurs in several cellular locations, including chloroplastic PSI and PSII [136], implying that elevations of chloroplastic ROS may be 
exploited by plant hosts for successful defence against pathogens, especially viruses that are often associated with chloroplasts (Fig. 1). In fact, the activation of a MAP-kinase cascade in tobacco leaves by TMV infection markedly promoted the generation of chloroplastic $\mathrm{H}_{2} \mathrm{O}_{2}$, playing an important role in the signalling for and/or execution of cell death during HR-type resistance to TMV. Accordingly, virus-infected tobacco plants kept in the dark did not accumulate $\mathrm{H}_{2} \mathrm{O}_{2}$ in chloroplasts after MAPK activation and cell death was significantly delayed, pointing to a possible role of chloroplast-generated ROS in virus resistance [96]. The oxygenevolving complex (OEC) of PSII in chloroplasts is in fact a potential site of ROS generation [see e.g. [91]]. Recently, Balasubramaniam and coworkers [13] have demonstrated that the PSII OEC protein PsbP specifically interacts with the coat protein (CP) of alfalfa mosaic virus (AMV). In high concentrations, PsbP may inhibit virus replication, implying a function in antiviral defence with a likely involvement of chloroplast-originated ROS generation that could result in resistance to AMV [13]. Taken together, it seems that chloroplast-associated ROS generation could be an often underappreciated pivotal factor of virus resistance.

Excess reducing power generated in chloroplasts through photosynthesis can be diverted e.g. to peroxisomes by the export of glycolate. In peroxisomes, glycolate is first metabolized to glyoxylate by glycolate oxidases, a reaction that generates $\mathrm{H}_{2} \mathrm{O}_{2}$ during a process called photorespiration. The primary function of class 1 catalases is the removal of $\mathrm{H}_{2} \mathrm{O}_{2}$ produced during photorespiration in leaf peroxisomes [150]. The role of peroxisome-generated $\mathrm{H}_{2} \mathrm{O}_{2}$ in HR-type resistance to plant viruses is supported by the study of Talarczyk et al. [145]. Overexpression of a yeast peroxisomal catalase $\mathrm{A} 1$ gene (CTA1) in tobacco revealed that the CTA1 protein is indeed localized in peroxisomes of tobacco cells and likely confers a reduction in resistance to TMV. Interestingly, the size of HR-type necrotic lesions was significantly larger in the infected leaves of these transgenic plants coupled with lower $\mathrm{H}_{2} \mathrm{O}_{2}$-levels around lesions. This suggests that peroxisomal $\mathrm{H}_{2} \mathrm{O}_{2}$ is indeed functional in limiting virus replication and/or movement during HR-type virus resistance, which is also supported by observations that plant class 1 catalase genes and catalase activity are transiently suppressed in HR-type necrotic lesions elicited by TMV and tobacco necrosis virus (TNV) [39,86,153,154] (Fig. 1).

In summary, the data discussed above point to an important role of ROS produced by various intracellular organelles (mitochondria, chloroplasts, peroxisomes) during the establishment of incompatible plant-virus interactions.

\subsection{Interplay between oxidative stress, antioxidants and salicylic acid metabolism in the process of virus resistance}

Several lines of evidence show that the formation of ROS is linked to the metabolism of the essential defence hormone salicylic acid (SA) in a feedback-loop [40,137]. ROS and SA also interplay with $\mathrm{GSH}$ in stressed plants [73]. Exogenous $\mathrm{H}_{2} \mathrm{O}_{2}$ induced the accumulation of free benzoic acid and SA in Xanthi-nc tobacco leaves $[92,115]$. In turn, SA was found to inhibit the activity of the $\mathrm{H}_{2} \mathrm{O}_{2}$-decomposing enzymes catalase $[23,43]$ and ascorbate peroxidase (APX) [42]. Recently developed high throughput screens identified a large number of novel SA-binding enzymes, several of which were associated with redox regulation [100]. Interestingly, SA did not affect the mRNA expression of a cytosolic APX gene ( $C A P X)$ during TMV-induced HR, while expression of $C A P X$ was activated by protein phosphorylation and ion fluxes and suppressed by low oxygen pressure [108]. The ability of SA to elevate $\mathrm{H}_{2} \mathrm{O}_{2}$ levels by binding to antioxidant enzymes could explain the finding that SA potentiated both $\mathrm{H}_{2} \mathrm{O}_{2}$ accumulation and cell death in pathogen-infected soybean suspension cells [137]. In Arabidopsis thaliana SA treatments enhanced $\mathrm{H}_{2} \mathrm{O}_{2}$ production, lipid peroxidation and oxidative damage. SA-enhanced $\mathrm{H}_{2} \mathrm{O}_{2}$ levels were related to increased activities of $\mathrm{Cu}, \mathrm{Zn}$-superoxide dismutase (SOD). Furthermore, SA-mediated oxidative damage required $\mathrm{H}_{2} \mathrm{O}_{2}$ [123]. Interestingly, the level of SA is physiologically coupled not only to that of $\mathrm{H}_{2} \mathrm{O}_{2}$ but also to the major antioxidant glutathione. $\mathrm{SA}$ and GSH were shown to mutually induce each other in A. thaliana leaves [102]. It was also demonstrated that GSH increases intracellular $\mathrm{H}_{2} \mathrm{O}_{2}$ to activate $\mathrm{SA}$ signalling. It seems that the tight physiological interplay between $\mathrm{SA}, \mathrm{H}_{2} \mathrm{O}_{2}$ and $\mathrm{GSH}$ levels is required to cope with oxidative stress and pathogen defence during abiotic and biotic stresses that induce SA biosynthesis [73,102].

Systemic acquired resistance (SAR) is typically induced by viral and other pathogenic infections that result in tissue necrosis, where the initial microbial attack causes resistance to subsequent pathogen challenge in distal plant parts. HR-type resistance is often associated with the activation of SAR [50,59,129,142]. ROS, together with SA, were suggested to play a pivotal role in the establishment of SAR [23,44]. Interestingly, oxidative stress during HR-type resistance of tobacco to TMV was shown to be signalled by downregulation of an antioxidant because an elevated level of monodehydroascorbate (MDHA) radicals was detected by electron paramagnetic resonance spectroscopy [48]. Furthermore, the TMVelicited SAR induced in remote leaves of this host plant was also associated with stimulated MDHA signals indicative of a microoxidative burst.

Enzymatic and non-enzymatic antioxidants are also activated during the development of SAR. Fodor et al. [47] have demonstrated that in uninfected upper leaves of TMV-inoculated, resistant tobacco plants glutathione levels and activities of glutathione reductase (GR), glutathione S-transferase (GST), and SOD increased 10-14 days after TMV inoculation of the lower leaves, concomitantly with the development of SAR. On the other hand, antioxidants were down-regulated in a transgenic tobacco expressing a gene of an SA-hydrolysing enzyme (nahG) that fails to develop SAR following e.g. virus infection [83]. These results suggest that some stimulated antioxidative processes could contribute to the suppression of necrotic symptom development in leaves exhibiting SAR. In fact, these findings demonstrate that the dual role of ROS (i.e. localized pathogen inhibition/oxidative stress and antioxidant induction) is also functional during plant SAR effective against pathogens, including viruses.

\subsection{Antioxidative mechanisms in incompatible plant-virus- interactions}

As mentioned previously, plants possess multiple biochemical mechanisms that detoxify $\mathrm{O}_{2}{ }^{--}$and $\mathrm{H}_{2} \mathrm{O}_{2}$ thereby inhibiting programmed cell death. $\mathrm{O}_{2} \cdot-$ can be dismutated by various SOD isoenzymes to $\mathrm{H}_{2} \mathrm{O}_{2}$, whereas $\mathrm{H}_{2} \mathrm{O}_{2}$ is reduced by catalase enzymes, peroxidases or by the ascorbate-glutathione cycle $[18,106,149]$. Interestingly, TMV infection markedly influences the antioxidative systems of hypersensitively reacting resistant Xanthi-nc tobacco. Appearance of HR-type symptoms after TMV inoculation was preceded by a slight, transient decline in activities of the key $\mathrm{H}_{2} \mathrm{O}_{2}$ detoxifying enzymes APX, GR, GST and SOD in the inoculated leaves, but after the onset of necrosis all these activities and glutathione levels substantially increased [47,61]. In accordance with these results, the expression of a cytosolic APX (CAPX) was found to be post-transcriptionally suppressed during TMV-induced HR type resistance in resistant tobacco leaves. Although the steady state level of transcripts encoding CAPX was induced, the level of cAPX protein declined due to inhibited protein biosynthesis, possibly at the level of translation elongation [107]. In addition, it has been demonstrated that mRNA levels of a tobacco catalase 
(CAT1) along with catalase activity are transiently suppressed in HR-type lesions during infection by TMV and TNV [39,86,153,154]. It was also shown that CAT1 is repressed only in the zone directly surrounding necrotic lesions, while its expression is high in adjacent, healthy tissues [39,154]. Accordingly, induced plant juvenility resulted in elevated antioxidant enzyme activities and increased HR-type resistance (i.e. less necrotic lesions and decreased pathogen accumulation) to TNV in tobacco [121]. These studies imply that a temporal and spatial control of antioxidant enzymatic activity at virus entry sites could drive localized, transient ROS accumulation leading not only to programmed plant cell/tissue death but also a significant limitation of virus movement and/or replication that ultimately results in resistance.

Non-enzymatic antioxidants may also have a marked effect on virus resistance. This was shown for the tripeptide glutathione (GSH) that exerts a pronounced influence on TMV infection in resistant plants. Treatment of Xanthi-nc tobacco leaves with the synthetic GSH-precursor L-2-oxothiazolidine-4-carboxylic acid (OTC) markedly increased GSH levels. In addition, OTC pretreatment considerably decreased both the number of necrotic lesions and the virus content in TMV-infected leaf discs [62]. Also, tobacco grown with a sufficient sulphate supply displayed significantly less HR-type necrotic lesions and reduced TMV accumulation coupled with at least 50\% higher GSH levels in most intracellular organelles (mitochondria, chloroplasts, nuclei, peroxisomes and cytosol) as compared to controls [81]. These results point to the differential roles of GSH during virus resistance not only as an antioxidant but also as a defence signalling compound.

\subsection{ROS accumulation may result in virus resistance with or without plant cell/tissue death}

As discussed above, virus recognition by attacked plants may result in localized programmed cell death associated with pathogen restriction at infection sites. This phenomenon often culminates in the formation of macroscopically visible localized necrotic lesions, the HR) [see e.g. in [56,57,84]]. Macroscopic cell and tissue death during HR often seems to be tightly linked to pathogen resistance. However, it is possible to uncouple cell death from resistance during infections by e.g. viruses [5,15,31,80,113,144]. Nevertheless, the existence of independent resistance and cell death responses within an HR does not exclude the possibility that cell death has a role in reinforcing or stimulating the induction of defences and pathogen localization [see e.g. [57,69,89]].

It is well documented that the HR in response to pathogens, including viruses, is associated with an oxidative burst (Fig. 1). This means a rapid and localized ROS accumulation including NADPH oxidase-mediated production of $\mathrm{O}_{2}{ }^{--}$[see e.g.[38,80,109],discussed above] but also the generation of $\mathrm{H}_{2} \mathrm{O}_{2}$. For example, infection of tobacco with TMV induces at least two peroxidase isozymes in virus-inoculated leaves [87]. In fact, certain peroxidase isozymes are known to participate in generating $\mathrm{H}_{2} \mathrm{O}_{2}$ necessary for pathogen defence [117]. In addition, a significant increase in the activity of the $\mathrm{H}_{2} \mathrm{O}_{2}$-producing uricase enzyme was detected in hypersensitively reacting tobacco leaves following TMV inoculation [112]. Furthermore, elevated $\mathrm{O}_{2}{ }^{\cdot-}$ production and SOD activity that generates $\mathrm{H}_{2} \mathrm{O}_{2}$ from $\mathrm{O}_{2}{ }^{-}$- was observed in tobacco ringspot virus (TRSV) inoculated resistant cowpea leaves that develop HR [46]. These results suggested for the first time that a consistent increase in $\mathrm{H}_{2} \mathrm{O}_{2}$ formation may be also associated with host cell death and resistance during a virus-elicited $\mathrm{HR}$. In fact, the application of histochemical staining methods (3,3'-diaminobenzidine, DAB and 2,7'-dichlorofluorescin diacetate, DCFH-DA) revealed a localized, long-lasting $\mathrm{H}_{2} \mathrm{O}_{2}$ accumulation in TMV-infected plants displaying HR-type resistance $[83,130]$. Another source of $\mathrm{H}_{2} \mathrm{O}_{2}$ during TMV- elicited HR was shown to be the accumulation of polyamines in tobacco leaf apoplasts. Polyamine infiltration into a healthy leaf induced the generation of $\mathrm{H}_{2} \mathrm{O}_{2}$ and simultaneously caused HR-like cell death. Furthermore, the $\mathrm{H}_{2} \mathrm{O}_{2}$-producing polyamine oxidase activity increased up to 3 -fold in the apoplasts during TMV-elicited HR [155].

The above-mentioned results point to the essential role of ROS in the activation of hypersensitive plant cell death and virus resistance. However, it seems that the temporal patterns (i.e. timing) of in planta ROS production may be instrumental in eliciting successful resistance responses to e.g. virus infections. We have shown that external application of $\operatorname{ROS}\left(\mathrm{O}_{2}{ }^{--}\right.$and $\left.\mathrm{H}_{2} \mathrm{O}_{2}\right)$ only $2 \mathrm{~h}$ after inoculation confers a symptomless resistance of tobacco otherwise susceptible to TMV, while ROS-treatments 3 days after inoculation do not elicit resistance, only HR-like cell and tissue death $[80,11]$. Such a symptomless, rapid resistance response to plant virus infections called extreme resistance indeed occurs in nature. Extreme resistance provides near total immunity against viruses like e.g. potato virus X (PVX), soybean mosaic virus (SMV) or turnip crinkle virus (TCV) $[15,33,65]$. In plants carrying the $R x 1$ gene conferring extreme resistance to PVX, transient expression of the PVX coat protein (the viral avirulence gene product) results in HRlike symptoms [15]. It seems that the resistance conditioned by $R \times 1$ to PVX is so fast that the PVX coat protein cannot reach a concentration sufficient to elicit HR. A similar model has been proposed to explain the resistance conferred by the HRT gene in A. thaliana to TCV. A. thaliana that carries HRT responds to TCV with HR but transgenic plants overexpressing $H R T$ to very high levels develop no HR but rather a symptomless extreme resistance upon TCV infection [33]. A possible biochemical mechanism of symptomless (extreme) resistance could be the direct antiviral effect of ROS accumulation at infection sites [15] in accordance with the role of externally applied ROS in conferring symptomless resistance to TMV [11]. Therefore, extreme resistance controlled by e.g. $R x 1$ could involve an early accumulation of e.g. $\mathrm{O}_{2}{ }^{\circ}, \mathrm{H}_{2} \mathrm{O}_{2}$, or perhaps ${ }^{\circ} \mathrm{OH}$, considered to be one of the most reactive ROS, causing thereby an almost complete arrest of virus replication.

Taken together, the efficiency of resistance during incompatible plant-virus interactions may depend on the speed of host response determined at least in part by an early and localized ROS accumulation at sites of virus infection. In other words a rapid, efficient host reaction (including fast, targeted ROS development) could result in early elimination of the virus without any disease symptoms (extreme resistance). On the other hand, a somewhat delayed and less efficient host response allows a certain degree of virus replication and movement resulting in oxidative stress and programmed death of affected plant tissues before conferring a final arrest of pathogen invasion (HR).

\section{Oxidative stress during compatible plant-virus interactions}

In contrast to incompatible plant-virus interactions, most of the knowledge about the involvement of ROS in symptom development and pathogenesis during compatible virus infections has been published in the last decade. Different authors showed that the symptom development associated with compatible plant-virus interactions is linked to the establishment of an oxidative stress (Fig. 2). In 2000, Riedle-Bauer [126] described that ROS accumulation as well as the balance between increased oxidative stress and antioxidant levels can play a role in the development of symptoms in systemically virus-infected plants. Other studies suggested that in a compatible plant-virus interaction, the early induction of antioxidant enzymes can interfere with the ROS signalling needed to enhance the defence reactions in the host, leading to a 


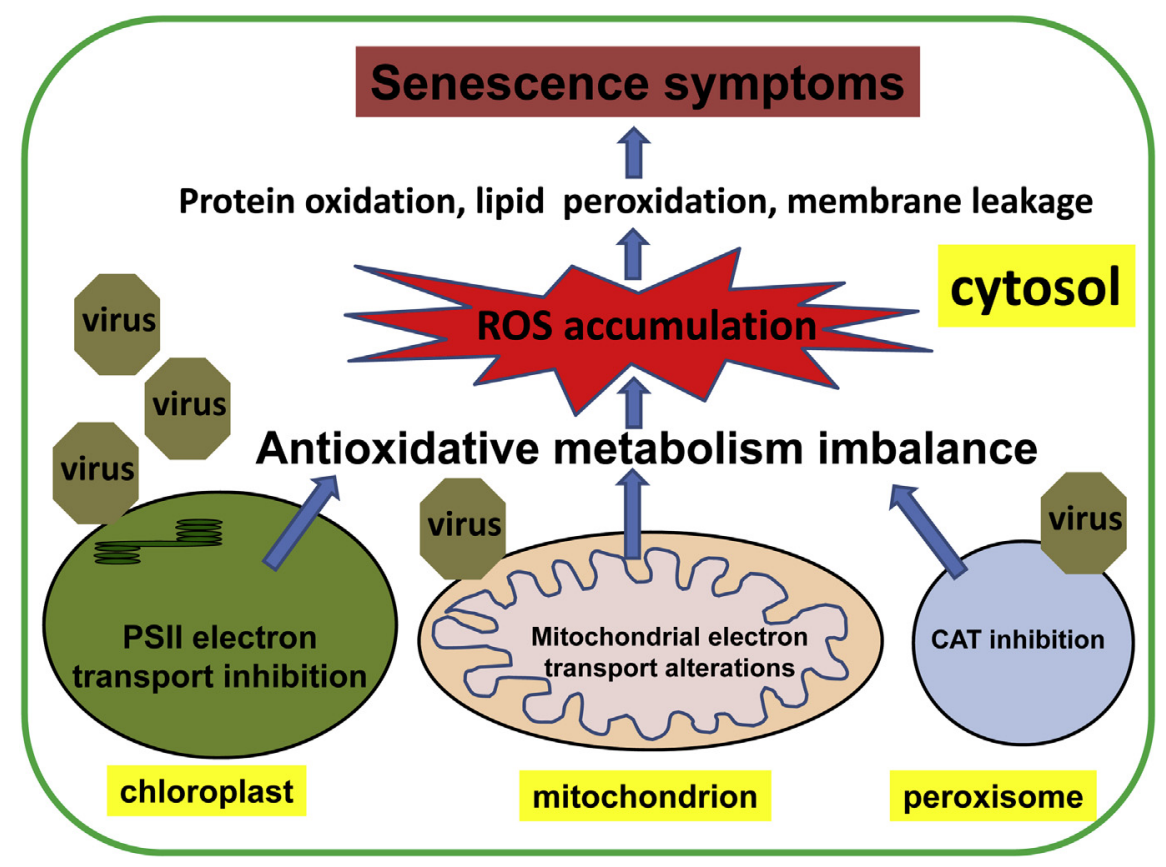

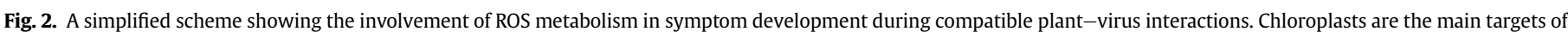

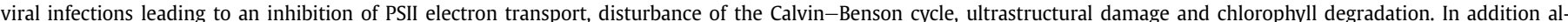

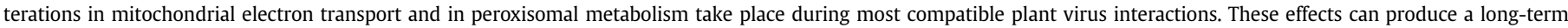

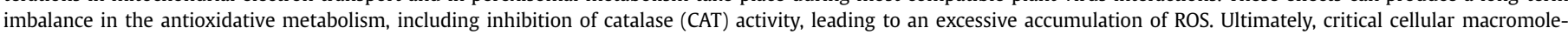

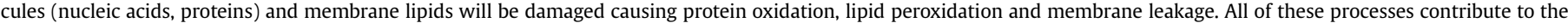
development of senescence-like symptoms.

compatible interaction [e.g. [7]]. However, the response of antioxidant enzymes in compatible plant-virus interactions is very varied and both increases and down-regulation of antioxidative defences has been reported $[26,71,94]$ (Table 1 ). These differential responses could be the result of different variables, including the particular plant-virus interaction, the inoculation procedure, the experimental period, the time of sampling, growth conditions, or metabolic differences of the studied plant species, etc. $[36,71,94]$.

\subsection{Plant-tobamovirus interactions}

The genus tobamovirus infects a huge range of host plants, including different crop species, leading to strong yield reductions [see e.g. [98,134]].

Different authors showed that in the photosynthetic electron transport chain in chloroplasts the PSII donor side is the main target in viral infections as observed in Nicotiana benthamiana plants infected with different strains of two tobamoviruses (pepper mild mottle virus, PMMoV and paprika mild mottle virus, PaMMoV). The infection reduced the electron transport efficiency in both symptomatic and asymptomatic leaves, as a result of the reduction of the fraction of open reaction centres and the efficiency of excitation capture by PSII. This was deduced from the low photochemical quenching ( $\mathrm{qP}$ ) and efficiency of excitation energy values $\left(\mathrm{F}^{\prime} \mathrm{v} / \mathrm{F}^{\prime} \mathrm{m}\right)$ recorded during the infection process [122]. The authors observed increased non-photochemical quenching (NPQ) values in all tobamovirus-infected plants reflecting an enhancement of energy dissipation mechanisms [122]. In addition, a reduction in the contents of the PSII oxygen-evolving complex polypeptides was found that affected the oxygen evolution rates of thylakoid membranes and leaves from infected plants [122]. The infection of plants by the Italian strain of PMMoV disturbed the Calvin Cycle as observed by decreased levels of mRNAs coding for the small Rubisco subunit and the light harvesting complex II (LHCII) [119] that can contribute to the remarkable increase in NPQ during the infection process. The authors proposed these parameters to assess the effect of tobamovirus infections in the chloroplasts [120]. Taken together, the above studies suggest that compatible tobamovirus infections facilitate the inhibition of PSII electron transport by disturbing the oxygen-evolving complex (OEC), a potential site of ROS generation [see also [1,91]]. In other words, virus-mediated inhibition of chloroplast-associated ROS generation could be an effective strategy of e.g. tobamoviruses to establish a compatible interaction with their plant hosts.

The effect of tobamovirus [tobacco mosaic virus (TMV) and tomato mosaic virus (ToMV)] infections on the temporal changes in peroxidase (POX), catalase, as well as in oxidative stress parameters $\left(\mathrm{H}_{2} \mathrm{O}_{2}\right.$ contents, lipid peroxidation and protein oxidation) was studied in the compatible hosts bell pepper and tomato [98]. Tomato seedlings showed a strong increase in POX activity at $24 \mathrm{~h}$ post-inoculation with TMV or ToMV, whereas bell-pepper displayed less increase in POX activity. Regarding catalase activity, in all cases, virus infection induced a reduction, especially in ToMVinfected bell pepper seedlings and TMV-infected tomato seedlings. These plant-virus interactions conferred accumulation of higher amounts of $\mathrm{H}_{2} \mathrm{O}_{2}$, and, accordingly, higher levels of protein oxidation and lipid peroxidation, respectively [98] (Table 1).

The role of ROS metabolism in symptom development and pathogenesis in $N$. benthamiana plants upon infection with two different strains of pepper mild mottle virus, the Italian (PMMoV-I) and the Spanish (PMMoV-S) strains was recently studied [66] (Table 1). The Italian strain was shown to be less virulent than the Spanish one and plants showed the capability to recover from PMMoV-I infection 21 days after inoculation (dpi). Interestingly, PMMoV-S-infected plants down-regulated the levels of three PSII oxygen-evolving complex (OEC) proteins, causing up to a $60 \%$ reduction in PsbO and PsbP and up to an $80 \%$ reduction in PsbQ as compared to healthy controls. In contrast, the levels of these 
Table 1

Responses of antioxidant defences during compatible plant-virus interactions.

\begin{tabular}{|c|c|c|c|c|}
\hline Interaction & Antioxidant & Response $^{\mathrm{a}}$ & Oxidative stress phenotype/symptoms & Reference \\
\hline \multirow[t]{2}{*}{ TMV-tomato 24 hpi } & POX & 4.8-fold increase & Not described & Madhunsudhan et al., 2009 \\
\hline & CAT & 4-fold decrease & & \\
\hline \multirow[t]{2}{*}{ TMV-pepper } & POX & 1.2 -fold increase & & \\
\hline & CAT & 1.8-fold decrease & & \\
\hline \multirow[t]{2}{*}{ ToMV-tomato } & POX & 2.3-fold increase & & \\
\hline & CAT & 1.5 -fold decrease & & \\
\hline \multirow[t]{2}{*}{ ToMV-pepper } & POX & 2-fold increase & & \\
\hline & CAT & 7.2-fold decrease & & \\
\hline \multirow{6}{*}{$\begin{array}{l}\text { PMMoV-I-N. benthamiana } \\
28 \mathrm{dpi}\end{array}$} & MnSOD & 2-fold increase & Symptom recovery & Hakmaoui et al., 2012 \\
\hline & FeSOD & 2-fold increase & & \\
\hline & CuZn-SOD I & 1.5-fold increase & & \\
\hline & CuZn-SOD II & 4-6 fold increase & & \\
\hline & APX & 3.7-fold increase & & \\
\hline & CAT & 2.4-fold decrease & & \\
\hline \multirow[t]{4}{*}{ PMMoV-S-N. benthamiana } & FeSOD & $70 \%$ decrease & $\begin{array}{l}\text { Decreased plant growth } \\
\text { Leaf curling }\end{array}$ & Hakmaoui et al., 2012 \\
\hline & CuZn-SOD I & $50 \%$ increase & Stunting & \\
\hline & APX & 2.4-fold increase & & \\
\hline & CAT & 2.4-fold decrease & & \\
\hline \multirow[t]{3}{*}{ ZYMV-C. sativus } & POX & 4-fold increase & Yellowing; severe malformations & Riedle-Bauer, 2000 \\
\hline & CAT & $64 \%$ increase & & \\
\hline & SOD & 2-fold increase & & \\
\hline \multirow[t]{4}{*}{ ZYMV-C. реро } & POX & 6.4-fold increase & & \\
\hline & CAT & $23 \%$ increase & & \\
\hline & SOD & $23 \%$ increase & & \\
\hline & GSH & $35 \%$ decrease & Yellowing, leaf deformation, stunting, mosaic pattern & Zechmann et al., 2007b \\
\hline \multirow[t]{10}{*}{ PPV-P. persica } & Sol-APX & $20 \%$ increase & Leaf deformation, interveinal chlorosis & Hernández et al., 2004 \\
\hline & Sol-SOD & $30 \%$ increase & & \\
\hline & Chl-APX & 8.5-fold increase & & \\
\hline & Chl-POX & $78 \%$ increase & & \\
\hline & Chl-MDHAR & $63 \%$ decrease & & \\
\hline & Chl-GR & $27 \%$ decrease & & \\
\hline & Chl-SOD & $27 \%$ decease & & \\
\hline & Ap-APX & $60 \%$ increase & & Díaz-Vivancos et al., 2006 \\
\hline & Ap-POX & $80 \%$ increase & & \\
\hline & Ap-NADH-POX & $100 \%$ increase & & \\
\hline \multirow[t]{10}{*}{ PPV-P. armeniaca } & Sol-APX & $32 \%$ decrease & Interveinal chlorosis and rings & Hernández et al., 2004 \\
\hline & Sol-DHAR & $20 \%$ decrease & & \\
\hline & Sol-CAT & $45 \%$ decrease & & \\
\hline & Sol-POX & $40 \%$ decrease & & \\
\hline & Chl-APX & $29 \%$ decrease & & \\
\hline & Chl-MDHAR & $50 \%$ decrease & & \\
\hline & Chl-DHAR & $39 \%$ decrease & & \\
\hline & Chl-GR & & & \\
\hline & Ap-POX & $47 \%$ decrease & & Díaz-Vivancos et al., 2006 \\
\hline & Ap-SOD & $33 \%$ decrease & & \\
\hline PPV-P. sativum & Sol-APX & $38 \%$ decrease & No visual symptoms & Díaz-Vivancos et al., 2008 \\
\hline $3 \mathrm{dpi}$ & Chl-APX & $53 \%$ decrease & & \\
\hline & Chl-POX & $32 \%$ decrease & & \\
\hline $15 \mathrm{dpi}$ & Sol-APX & $15 \%$ increase & Plant growth inhibition, chlorotic and necrotic spots & \\
\hline & Sol-GST & $25 \%$ decrease & & \\
\hline & Sol-POX & $95 \%$ increase & & \\
\hline & Sol-CAT & $34 \%$ decrease & & \\
\hline & Chl-MDHAR & $34 \%$ increase & & \\
\hline & Chl-GR & $39 \%$ decrease & & \\
\hline & Chl-GPX & $23 \%$ decrease & & \\
\hline & Chl-SOD & $35 \%$ decrease & & \\
\hline TuMV-Arabidopsis & Peroxidase 71 gene & Increased expression & Yellowing, senescence symptoms, arrest of flower growth & Manacorda et al., 2013 \\
\hline $\mathrm{PVY}^{\mathrm{NTM}}$-potato cV Igor & APX & Increased gene expression & Chlorotic and/or necrotic symptoms & Kogosek et al., 2010 \\
\hline & GPX & & & \\
\hline & GR & & & \\
\hline & GST & & & \\
\hline PVY-PVX-N. benthamiana & cytGR & Increased gene expression & Systemic necrosis & García-Marcos et al., 2009 \\
\hline & ChlGR & & Plant death & \\
\hline & CAT & & & \\
\hline & CuZn-SOD & & & \\
\hline SuCMoV-Sunflower L2 & SOD & $32 \%$ increase & Chlorotic mottling, growth reduction, yield losses & Arias et al., 2005 \\
\hline & CAT & $22 \%$ increase & & \\
\hline CMV-C. sativus & POX & 7.6-fold increase & Mosaic symptoms & Riedle-Bauer, 2000 \\
\hline & SOD & 2 -fold increase & Yellowing & \\
\hline & CAT & 2-fold increase & Malformations & \\
\hline CMV-C. реро & POX & 14-fold increase & & Riedle-Bauer, 2000 \\
\hline & SOD & 2 -fold increase & & \\
\hline
\end{tabular}


Table 1 (continued)

\begin{tabular}{|c|c|c|c|c|}
\hline Interaction & Antioxidant & Response $^{\mathrm{a}}$ & Oxidative stress phenotype/symptoms & Reference \\
\hline & & & Decreased plant growth & \\
\hline & & & Leaf curling & \\
\hline & & & Stunting & \\
\hline \multirow[t]{13}{*}{ CMV-Tomato } & chlSOD & 2-fold increase & Not described & Song et al., 2009 \\
\hline & mitSOD & $30 \%$ increase & & \\
\hline & solSOD & $16 \%$ increase & & \\
\hline & ChlAPX & $55 \%$ increase & & \\
\hline & mitAPX & 3.7-fold increase & & \\
\hline & solAPX & $70 \%$ increase & & \\
\hline & ChIMDHAR & $18 \%$ increase & & \\
\hline & mitMDHAR & $25 \%$ increase & & \\
\hline & solMDHAR & $16 \%$ increase & & \\
\hline & ChIDHAR & $46 \%$ increase & & \\
\hline & mitDHAR & $33 \%$ increase & & \\
\hline & solDHAR & $58 \%$ increase & & \\
\hline & solGR & 2-fold increase & & \\
\hline \multirow[t]{8}{*}{ CMV-Cucumber } & chlSOD & $90 \%$ increase & & \\
\hline & mitSOD & $70 \%$ increase & & \\
\hline & solSOD & $21 \%$ increase & & \\
\hline & mitAPX & 2-fold increase & & \\
\hline & ChIMDHAR & 2-fold increase & & \\
\hline & mitDHAR & $55 \%$ increase & & \\
\hline & mitGR & 2-fold increase & & \\
\hline & solGR & $18 \%$ decrease & & \\
\hline CMV-Arabidopsis & CAT & Decrease & Necrotic spots & Inaba et al., 2011 \\
\hline \multirow[t]{3}{*}{ CMV-Tobacco } & SOD & 2.6-fold increase & Chlorosis & Shang et al., 2010 \\
\hline & POX & $88 \%$ increase & Leaf deformation & \\
\hline & CAT & 3.3-fold increase & & \\
\hline WCIMV-bean & CAT & 17-fold decrease & Mild chlorosis & Clarke et al., 2002 \\
\hline \multirow[t]{3}{*}{$10 \mathrm{dpi}$} & GR & 6.7-fold decrease & & \\
\hline & SOD & 4.6-fold decrease & & \\
\hline & POX & 20-fold increase & & \\
\hline PepMV-tomato & CAT & Increase & & Mathioudakis et al., 2013 \\
\hline CfMV-D. glomerata & CAT & $75 \%$ increase & Chlorotic streaking, mottling & Li and Burrit, 2003 \\
\hline \multirow[t]{5}{*}{$3-5 \mathrm{dpi}$} & SOD & $30 \%$ decrease & & \\
\hline & APX & $55 \%$ decrease & & \\
\hline & MDHAR & $45 \%$ decrease & & \\
\hline & DHAR & $20 \%$ decrease & & \\
\hline & GR & $48 \%$ decrease & & \\
\hline \multirow[t]{5}{*}{ PNRSV-apricot seeds } & POX & $24 \%$ decrease & & \\
\hline & APX & $25 \%$ decrease & Increased lipid peroxidation & Amari et al., 2009 \\
\hline & MDHAR & $20 \%$ decrease & & \\
\hline & DHAR & $32 \%$ decrease & & \\
\hline & GR & $21 \%$ decrease & & \\
\hline
\end{tabular}

a "Increase" and "decrease" indicates changes in the activities of antioxidant enzymes, unless noted otherwise. Chl: chloroplast; mit: mitochondria; ap: apoplastic.

proteins were less affected in plants infected with the Italian strain of the virus [66]. However, the higher virulence of the Spanish strain was also reflected in a dramatic increase in some oxidative stress parameters. In fact, lipid peroxidation, protein oxidation (carbonyl-proteins) as well as lipoxygenase levels were much higher in $N$. benthamiana infected with PMMoV-S than in plants infected with PMMoV-I during the whole infection period assayed (up to $28 \mathrm{dpi}$ ). Initially, $\mathrm{H}_{2} \mathrm{O}_{2}$ levels increased at 7 and $14 \mathrm{dpi}$ in both cases, followed by a decrease. However, leaves infected with PMMoV-I reached similar values than controls, whereas leaves infected with PMMoV-S showed lower $\mathrm{H}_{2} \mathrm{O}_{2}$ levels at the same periods (i.e. between 14 and $28 \mathrm{dpi}$ ), suggesting an association between the suppression of ROS and maintenance of compatibility [66]. The effect of PMMoV infection on the antioxidative machinery was also different, depending on the infective strain. For example, the activity of various $\mathrm{H}_{2} \mathrm{O}_{2}$-generating SOD isozymes increased throughout the infection period in leaves infected with the Italian strain. However, the activity of Fe-SOD and Cu,Zn-SOD I isozymes decreased in PMMoV-S-infected leaves. Catalase activity was reduced in the infected leaves throughout the infection period, but especially at $28 \mathrm{dpi}$. In contrast, APX activity increased during the infection period from 14 dpi onwards in $N$. benthamiana plants infected with both virus strains, however, the increase being up to 4-fold in PMMoV-I-infected plants. In parallel with APX, an increase in monodehydroascorbate reductase (MDHAR) activity but a decrease in GR occurred with both viruses up to $21 \mathrm{dpi}$, and both antioxidant enzymes reached control values at $28 \mathrm{dpi}$. In addition, these authors observed that plants infected with the less virulent virus strain (PMMoV-I) maintained the levels of three peroxiredoxins, a recently identified group of $\mathrm{H}_{2} \mathrm{O}_{2}$-scavenging enzymes [66]. The severity of symptoms produced by both PMMoV strains was also related to the levels of the non-enzymatic antioxidants ASC and GSH. In this regard, ASC and GSH levels decreased in plants infected with the most virulent strain (PMMoV-S). In summary, it appears that in PMMoV-infected $N$. benthamiana the magnitude of oxidative stress and the antioxidant response is associated with (1) the severity of symptoms elicited by either PMMoV strains or (2) the elevated capacity of PMMoV-I-infected plants for symptom recovery, as compared to PMMoV-S-infected plants [66]. It is known that a successful recovery from virus-induced symptoms is often correlated with an almost complete absence of the pathogen $[32,124]$. Such a plant response could be conferred, at least in part by a localised, targeted accumulation of ROS with a side effect of elevated oxidative stress in host tissues.

As discussed above, the accumulation of ROS in incompatible plant-pathogen interactions (i.e. virus infections resulting in 
resistance) is regarded as an early and important mechanism for killing pathogens and/or suppressing symptom development $[38,64,80,82,103,147]$. In this sense, Bacsó et al. [11] showed that exogenous application of ROS, such as $\mathrm{H}_{2} \mathrm{O}_{2}$, or ROS-generating chemical systems to tobacco leaves two hours after TMV inoculation partially inhibited virus replication in the susceptible cultivar Samsum $n n$. In these experiments, the ROS-generating systems were glucose/glucose oxidase [for $\mathrm{H}_{2} \mathrm{O}_{2}$-generation, [152]] and riboflavin/methionine (for $\mathrm{O}_{2}{ }^{\cdot-}$ generation) [78]. The authors presented evidences that an early ROS accumulation (up to two hours after inoculation) can contribute to the development of resistance to TMV [11].

\subsection{Plant-potyvirus interactions}

Several researchers have studied the effects of infection by viruses of the potyvirus genus in different plant virus interactions. The most studied potyviruses include zucchini yellow mosaic virus (ZYMV), potato virus Y (PVY), turnip mosaic virus (TuMV) and plum pox virus (PPV) (Table 1).

The symptom development associated with compatible ZYMVinfections of Cucumis sativus and Cucurbita pepo plants was parallel to an enhanced effect on lipid peroxidation, indicative of membrane damage [126]. In both cases, infection with ZYMV enhanced the activity of several antioxidant enzymes. Accordingly, a strong induction of several POX isozymes occurred in both plant species. In addition, SOD and catalase activities were also increased, being much higher in the interaction ZYMV-C. sativus that in the ZYMV-C. pepo combination. The authors point out that the POX isoforms detected not only function as $\mathrm{H}_{2} \mathrm{O}_{2}$-scavengers but can also catalyse the formation of this ROS [see e.g. [17,117]] contributing to the oxidative stress in systemic plant-virus interactions.

It has been reported that ZYMV infection affected the contents of glutathione as well as its precursors in different cell compartments [157,158]. These authors observed a strong decrease in cysteine and glutamate in all cell compartments of ZYMV-infected young and old leaves of $C$. pepo plants. In contrast, glycine levels increased in all cell compartments from young leaves but were strongly reduced in old leaves, indicating that glycine is the limiting factor for GSH biosynthesis during compatible ZYMV infections in older leaves of $C$. pepo plants [157]. According to these authors, the loss of ability to provide enough GSH could be responsible for symptom development in old leaves that ultimately lead to virusinduced senescence and cell death. The importance of GSH in reducing virus content and symptom development was confirmed by the same research team [158]. The treatment with 1 mM OTC, an artificial cysteine precursor, increased the GSH content in young and old leaves of ZYMV-infected $C$. pepo plants. This response was linked to a strong decrease in virus contents as well as a reduced and delayed symptom development [158].

Two compatible plant-virus interactions where host antioxidative metabolism has been well characterized are the plum pox virus (PPV)-Prunus and PPV-pea interactions. PPV is the causal agent of Sharka disease, one of the most important virus diseases reducing fruit production [19]. The first report on the effect of PPV infection on the antioxidative metabolism in Prunus spp. was published in 2001 [70]. The authors studied the effect of PPV on the activities of several antioxidant enzymes in leaves of two apricot cultivars, one resistant and another susceptible. Common responses observed in both cases were the decrease in catalase activity. Based on the differential effects of PPV infection on SOD (a $\mathrm{H}_{2} \mathrm{O}_{2}$-producer enzyme) and APX ( $\mathrm{an} \mathrm{H}_{2} \mathrm{O}_{2}$-scavenger enzyme), the authors suggested a role for $\mathrm{H}_{2} \mathrm{O}_{2}$ in the response to PPV in incompatible interactions [70]. Later, however, the same authors described that long-term PPV-infections produce an imbalance in the antioxidant machinery in compatible PPV-plant interactions. In fact, susceptible plants develop a virus-induced oxidative stress in systemically infected leaves [29,35,36,71,72].

As a consequence of long-term PPV infection, an oxidative stress was produced in peach leaves, as reflected by the increase in lipid peroxidation, protein oxidation and $\mathrm{H}_{2} \mathrm{O}_{2}$ accumulation. In young leaves (2-week-old-leaves), an increase in lipid peroxidation was also observed, although the values were lower than those observed in old leaves (4-week-old-leaves). Long-term PPV infection increased APX activity and reduced SOD in soluble fractions, whereas in chloroplast fractions, again an increase in APX took place but a decrease in SOD, MDHAR and GR was observed [71]. In addition, a decrease in NPQ was observed in PPV-infected peach leaves, which could reflect a decreased capacity for the safe dissipation of excess light energy [104]. The effect of PPV infection on the response of antioxidant enzymes was also studied in a PPVsusceptible apricot cultivar (cv. Real Fino). Similar to that described in peach leaves, a compatible PPV infection also produced an oxidative stress in apricot leaves, as monitored by increases in the oxidative stress parameters described above (lipid peroxidation, protein oxidation and $\mathrm{H}_{2} \mathrm{O}_{2}$ accumulation). In soluble fractions, the authors reported a decrease in APX and DHAR, whereas a reduction of catalase and POX was also observed. On the other hand, an imbalance in the ASC-GSH cycle enzymes occurred in chloroplast fractions since all of these enzymes displayed significant decreases in activity [72]. Moreover, a decrease in fluorescence chlorophyll parameters took place in apricot leaves. Based on these data observed in peach and apricot, the authors suggested that chloroplasts seemed to be more severely affected by PPV infection than the cytosolic compartment.

The response of the apoplastic antioxidant system in PPVinoculated susceptible (peach cv. GF305 and apricot cv. Real Fino) Prunus plants was studied by the same research team. PPV infection caused an oxidative stress also in the apoplastic space of apricot and peach plants, as observed by the increase in $\mathrm{H}_{2} \mathrm{O}_{2}$ contents in this compartment that was accompanied by an increase in leaf electrolyte leakage measured in leaf sections [35].

All the above mentioned results on virus-induced plant oxidative stress were obtained following long-term PPV infections. However, different factors, including the use of woody plants, the mode of inoculation and the time passed between the exposure of plants to artificial dormancy and the growth of the first expanding leaves makes it difficult to study the early responses to PPV infection. Therefore, Diaz-Vivancos et al. [36] used a PPV-susceptible herbaceous plant in order to study biochemical and physiological effects of short term PPV infection. For this purpose, a recombinant PPV strain encoding GFP was used to infect a susceptible pea cultivar (Pisum sativum cv. Alaska). At three days post-inoculation (dpi) an alteration in chloroplast metabolism was detected, as observed by an increase in chloroplast $\mathrm{H}_{2} \mathrm{O}_{2}$ levels and a decrease in the enzymatic mechanisms involved in its elimination (APX and POX activities). These changes observed in chloroplast fractions were accompanied by a reduction in soluble APX [36]. PPVinfection induced more severe changes in antioxidant metabolism during long-term (15 dpi) than during short-term ( $3 \mathrm{dpi}$ ) exposure to the virus. In susceptible pea plants, long-term PPV-infection produced an oxidative stress, similar to that described previously for peach and apricot. In this sense, an increase in lipid peroxidation, protein oxidation, and electrolyte leakage, as well as elevated $\mathrm{H}_{2} \mathrm{O}_{2}$ levels in soluble fractions and chloroplasts from infected pea leaves was observed [36]. In addition, in spite of the increase in activities of certain $\mathrm{H}_{2} \mathrm{O}_{2}$-scavenging enzymes in soluble fractions (APX and POX), $\mathrm{H}_{2} \mathrm{O}_{2}$ accumulated in this fraction, parallel to decreased GST and catalase activities [36]. In chloroplasts, PPV infection caused a decrease in GPX, GR and SOD as well as an 
increase in MDHAR. Moreover - similar to PPV-infected peach leaves - a decrease in the NPQ parameter and decreased chlorophyll levels in isolated chloroplasts as well as ultrastructural damage to chloroplasts was noticed. Chloroplasts seem to be the cell organelles that are severely affected in PPV-infected cells, suggesting that chloroplasts could be a source of oxidative stress during the progression of viral infection $[29,30,35,36,71,72]$ (Fig. 2). Taken together, it seems that the strong systemic burst of $\mathrm{H}_{2} \mathrm{O}_{2}$ in PPV-infected plants that exhibit severe symptoms might be attributed, at least in part, to a delayed and failed attempt by the host to elicit resistance to the virus in systemic tissues. This is in agreement with other findings that demonstrate the pivotal role of timely ROS accumulation in virus resistance (see above) [e.g.38,80,103].

Following the demonstration that PPV causes an oxidative stress in infected leaves, Clemente-Moreno et al. [27,29] carried out different experiments in order to test if the increase of the antioxidative capacity of host plants would enhance resistance to PPV. Pea and peach plants were treated with OTC or BTH prior to PPV inoculation, and results showed that both treatments partially reduce PPV symptoms in pea and peach plants. However, in the latter case, the differences were only statistically significant in OTCtreated plants. In pea plants, increases in antioxidant mechanisms, such as enhanced activities of DHAR, GR, Glucose-6-phosphate dehydrogenase (G6PDH), APX and POX were observed in BTH and/or OTC-treated plants, which could play a role in reducing the severity of cellular damage induced by Sharka disease. In addition, asymptomatic leaves of infected plants displayed a higher redox state of glutathione, a process that could also play a role in the reduction of symptoms.

In peach plants, OTC, in addition to improving plant growth, provided protection to chloroplasts, as observed by the effect of PPV on fluorescence chlorophyll parameters, ultrastructural changes, induction of photosynthesis-related proteins and GPX activity in infected leaves [29]. It was suggested that OTC could be potentially applied in farming practice based on its effects in improving plant growth as well as protecting crops against pathogens. However, the timing of OTC application seems to be pivotal to afford protection against plant viruses, at least against PPV, since the in vitro treatment of infected micropropagated peach plants (cv. GF305) with either OTC or BTH did not reduce virus contents [28]. Indeed, the GF305 plantlets showed higher virus contents in the presence than in the absence of the treatments with OTC or BTH. In particular, plantlets treated with low BTH concentrations $(10 \mu \mathrm{M})$ exhibited the highest growth rate and the highest virus contents. In relation to this observation, it has been reported that an active growth of the host is required for an optimal virus replication [see e.g. [75] and references within].

Turnip mosaic virus (TuMV) is one of the most damaging potyviruses infecting members of the Brassicaceae family [99]. A. thaliana Col. 0 plants infected with the TuMV UK1 strain developed senescence symptoms, including a general yellowing of the rosette and leaf death at $21 \mathrm{dpi}$. Senescence symptoms correlated with decreased chlorophyll levels and strong ROS accumulation $\left(\mathrm{H}_{2} \mathrm{O}_{2}\right.$ and $\left.\mathrm{O}_{2}{ }^{--}\right)$[99]. The ROS accumulation was parallel to the induction of the peroxidase 71 gene (At5g64120) encoding a cellwall peroxidase that is involved in ROS production and known to participate in plant defence reactions. In addition, an unchanged level of CSD2 transcripts, encoding for chloroplastic Cu,Zn-SOD and an induction of its negative regulator miR398 was observed [99]. Interestingly, miR398 is also upregulated during deficiency of $\mathrm{Cu}$, the micronutrient involved in CuZn-SOD gene expression at the post-transcriptional level [51].

Potato virus $Y$ (PVY) is economically the most important viral potato pathogen. The three most common PVY isolate groups described are $\mathrm{PVY}^{\mathrm{N}}$, $\mathrm{PVY}^{\mathrm{O}}$ and $\mathrm{PVY}^{\mathrm{C}}$ [138]. The early response of two potato cultivars, Igor and Nadine, to two PVY isolates, the aggressive PVY ${ }^{\mathrm{NTN}}$ and the mild PVY ${ }^{\mathrm{N}}$, was monitored [85]. PVY ${ }^{\mathrm{NTN}}$ inoculated leaves developed chlorotic and/or necrotic ringspot lesions at 5-7 dpi. However, PVY ${ }^{\mathrm{N}}$ inoculation produced mild chlorotic ringspot symptoms. The PVY ${ }^{\mathrm{NTN}}$-infected Igor plants displayed a higher expression of certain antioxidant-related genes, such as APX, GPX, GR and GST than plants infected with the mild PVY stain. However, the response was the inverse in the PVY-infectedNadine cultivar [85], suggesting that host-dependent differential patterns of antioxidant induction could contribute to altered symptom severity in response to different PVY isolates.

Sunflower chlorotic mottle virus ( $\mathrm{SuCMoV}$ ) is a recently described potyvirus producing systemic infections in sunflower and causing chlorotic mottling, growth reduction and yield losses [7]. These authors studied if increases in antioxidants can interfere with the ROS signalling needed for defence reactions in the host. For this purpose they used two different sunflower lines, the more susceptible L2, and L3, showing less susceptibility. In response to SuCMoV infection, L2 developed severe chlorotic mottling symptoms whereas L3 presented isolated chlorotic pinpoints. When these symptoms became evident, the more susceptible line (L2) presented an increased lipid peroxidation, while SOD and catalase activities increased before the appearance of symptoms. The treatment of L2 plants with salicylic acid (SA) abolished the early SOD and catalase induction and reduced virus accumulation [7]. In accordance with these results, the authors concluded that an early increase in antioxidant activities after a viral infection can facilitate virus systemisation in compatible interactions [7]. In contrast, an early and efficient ROS accumulation and signalling would result in virus suppression even in compatible infections, as also demonstrated for e.g. Tobamoviruses (see above) [11,66].

\subsection{Plant-cucumovirus interactions}

Cucumber mosaic virus (CMV), the most important cucumovirus studied, infects important crop species such as tomato, celery, pepper and cucumber, producing important economic losses [140] by affecting vital metabolic processes such as photosynthesis and respiration $[21,140]$. In that respect, long-term CMV-infection produced a strong decrease in net photosynthesis rate in cucumber and tomato plants, that correlated with a significant reduction in $\mathrm{qP}$ and Y(II) chlorophyll fluorescence parameters [140]. In addition, these authors showed that CMV infection also reduced the mitochondrial electron transport at the level of complex I and II. The infected plants implement some defence mechanisms such as increases in NPQ and the alternative oxidase pathway as protective mechanisms to avoid oxidative stress in the chloroplasts and mitochondria [104,111]. However, in spite of the induction of these defence mechanisms, long-term CMV infection increased leaf $\mathrm{H}_{2} \mathrm{O}_{2}$ contents. The $\mathrm{H}_{2} \mathrm{O}_{2}$ increase occurred mainly at the chloroplast and mitochondrial levels (Fig. 2), in accordance with the imbalance observed in the photosynthesis and respiratory electron transport chains. All these changes parallelled a general increase in activities of different antioxidant enzymes, such as SOD and the ASC-GSH cycle enzymes in chloroplasts and mitochondria that cannot avoid oxidative stress in CMV-infected tomato and cucumber plants [140] (Table 1).

In a more recent work Inaba et al. [76] described that the necrotic spot symptoms produced in CMV-infected Arabidopsis plants are associated with an increase in $\mathrm{H}_{2} \mathrm{O}_{2}$ production. The $\mathrm{CMV}$-induced oxidative stress seemed to be provoked by a direct inhibition of catalase activity due to the direct interaction of the CMV $2 \mathrm{~b}$ protein with the isoenzyme catalase 3 (CAT3) in infected tissues. To corroborate the role of the CMV $2 \mathrm{~b}$ protein in the 
infection process, these authors generated transgenic Arabidopsis plants overexpressing the $2 \mathrm{~b}$ protein and they observed a correlation between the extent of necrotisation in leaves with a $50 \%$ decrease in catalase activity (Table 1 ) and the accumulation of $\mathrm{H}_{2} \mathrm{O}_{2}$. Furthermore, Inaba et al. [76] overexpressed the CAT3 gene in Arabidopsis and observed a delayed onset of necrosis and a suppression of CMV multiplication, at least 7 days post-inoculation (dpi). However, in more advanced infection stages (14 dpi) the levels of CMV viral particles in CAT3 plants reached the levels of non-transformed plants infected with CMV. The authors concluded that the overexpression of CAT3 gene can confer a partial resistance to CMV at least at an early phase of infection [76].

Shang et al. [135] reported a differential response between the infected yellow leaf tissues and the so-called "dark green islands" (DGIs) in N. tabacum leaves systemically infected with CMV. DGIs are defined as a cluster of green leaf cells free of virus but surrounded by yellow leaf tissues where the virus is present [10]. The DGI tissues are virus-resistant, whereas the yellow leaf tissues seem to be susceptible to the virus. The susceptible area showed a reduction in chlorophyll contents that correlated with a decreased photosynthesis rate, stomatal conductance and the decrease in some chlorophyll fluorescence parameters (Fv'/Fm'; Fv/Fm, $\phi_{\text {PSII }}$ ), while the DGIs values were closer to healthy tissues. The yellow leaf tissues accumulated more $\mathrm{H}_{2} \mathrm{O}_{2}$ than the DGIs but, interestingly, the contrary occurred for $\mathrm{O}_{2}{ }^{-\cdots}$ accumulation. According to the authors, this response can be due to the relatively low SOD activity observed in the DGIs after CMV infection. As a consequence of $\mathrm{H}_{2} \mathrm{O}_{2}$ accumulation in the yellow leaf tissue, an increase in catalase and POX activities occurred. In addition, a strong increase in the activity of SOD (an $\mathrm{H}_{2} \mathrm{O}_{2}$-generating enzyme) was observed in these virussusceptible areas that can partially account for the increased $\mathrm{H}_{2} \mathrm{O}_{2}$ accumulation. As a consequence of the ROS accumulation in infected leaves, an increase in lipid peroxidation was produced in both leaf tissues although the cell damage was much higher in the yellow leaf tissue than in the DGIs and electrolyte leakage, indicating reduced membrane stability and integrity, showed an increase only in these susceptible tissues [135] (Table 1). The abovementioned results support the idea that in compatible plant-virus interactions a massive oxidative stress, marked by $\mathrm{H}_{2} \mathrm{O}_{2}$-generation, may occur in susceptible tissues that can contribute to the onset of disease symptoms. On the other hand, virus free DGI tissues contain less $\mathrm{H}_{2} \mathrm{O}_{2}$ but higher than normal amounts of $\mathrm{O}_{2}{ }^{-}$ which seems to be the cause of virus resistance in these tissue sections. Apparently, this process might reflect a delayed but failed attempt by the host to fully suppress virus accumulation in systemically infected tissues.

\subsection{Plant-potexvirus interactions}

In 2002 Clarke et al. [26] studied the compatible interaction of white clover mosaic virus (WCIMV) and bean plants. They observed that the activity of several antioxidant enzymes (catalase, GR and SOD) rapidly declined in the first few days after WCIMV infection. However, the treatment of plants with the plant hormones dihydrozeatine, SA or jasmonic acid (JA) prior to the infection reduced virus replication and induced an increase in catalase, GR and POX. These authors proposed that a decline in ROS-scavenging capacity may be required for a rapid increase in virus replication in the early stages of infection. On the other hand, treatments that stimulate antioxidant capacity may interfere with initial virus replication and spread, preventing the establishment of the virus and the progression of the disease [26] (Table 1).

Recently, however, Mathioudakis et al. [103] described that an increase in catalase activity can promote pepino mosaic virus (PepMV) infection in tomato and $N$. benthamiana plants. In this work, the authors described that the interaction between the PepMV protein p26 and the tomato CAT1 isozyme increased catalase activity and therefore, the $\mathrm{H}_{2} \mathrm{O}_{2}$ scavenging capacity (Table 1). In addition, in healthy $N$. benthamiana plants, the transient expression of the p26 protein also increased catalase activity whereas CAT1-silenced plants showed a reduced viral replication. All these data demonstrate the importance of a tight regulation of temporal and spatial $\mathrm{H}_{2} \mathrm{O}_{2}$-generation to activate plant defences in order to cope with viral infections [103].

The potexvirus potato virus $\mathrm{X}$ (PVX) has been used in mixed infections in order to study molecular events associated with plant-virus interactions (García-Marcos et al., 2009). The coinfection of $N$. benthamiana plants with PVY and PVX increased the systemic symptoms leading to necrosis of the newly emerging leaves and plant death compared with single infections [52]. In upper, non-inoculated leaves an oxidative stress was produced with the mixed infection, as monitored by increased lipid peroxidation values and $\mathrm{O}_{2}{ }^{--}$accumulation, mainly in the chloroplasts. In response to this oxidative stress, a higher expression of different genes encoding antioxidant enzymes was observed, including cytosolic and chloroplastic GR, catalase and $\mathrm{Cu}, \mathrm{Zn}$-SOD. In a follow-up work, the same research team studied the effect of the synergistic interactions of PVX with a number of PPV clones in $N$. benthamiana plants [118]. In this work, they used the infectious cDNA clones PVX-HCWT and PVX-HCLH. The first construct, that expressed the wild type HC-Pro gene from PPV, displayed an enhanced pathogenicity, whereas PVX-HCLH, containing a mutated variant of PPV HC-Pro, was unable to induce systemic necrosis [118]. In fact, PVX induced a strong necrosis response coupled with $\mathrm{H}_{2} \mathrm{O}_{2}$ production when co-expressing HCWT. In addition, the interaction $N$. benthamiana-PVX-HCWT caused an increase in SA, JA and ABA concentrations. However, in spite of the increase in $S A$ and $P R-1$ expression, plants were unable to restrain virus multiplication and the spread of the pathogen to the upper part of the plants [118]. Recently, Aguilar et al. [2] showed that the infection of $N$. benthamiana plants with a PPV recombinant virus expressing the P25 protein from PVX leads to a higher $\mathrm{H}_{2} \mathrm{O}_{2}$ accumulation as compared to plants infected with PPV-GFP. These results suggested that the P25 protein is the main pathogenic determinant involved in eliciting HR-like local and systemic necrotic responses in synergistic infections involving PVX and potyviruses like PPV [2].

\subsection{Other viruses}

\subsubsection{Plant-sobemovirus interactions}

The effect of sobemovirus infections on plant antioxidative metabolism has been barely studied. In 2003, Li and Burrit [94] carried out an interesting study on antioxidative metabolism in the compatible interaction cocksfoot mottle virus (CfMV)-Dactylis glomerata L. (also known as cocksfoot or orchardgrass) (Table 1). CfMV infects different cereal species, including oats, barley or wheat [94]. The authors found a $50 \%$ decrease in $\mathrm{H}_{2} \mathrm{O}_{2}$ during the first 3 days following CfMV inoculation, but afterwards $\mathrm{H}_{2} \mathrm{O}_{2}$ increased gradually, reaching a $150 \%$ increase at the end of the experimental period (up to 21 days). The time course of $\mathrm{H}_{2} \mathrm{O}_{2}$ levels was correlated with $\mathrm{H}_{2} \mathrm{O}_{2}$-scavenging catalase activity: the reduction in $\mathrm{H}_{2} \mathrm{O}_{2}$ contents observed during the first days of infection correlated with an increased catalase activity, whereas the $\mathrm{H}_{2} \mathrm{O}_{2}$ accumulation afterwards, during the development of the disease, correlated with a decline in catalase activity. When symptoms appeared, an $\mathrm{H}_{2} \mathrm{O}_{2}$ increase occurred favouring the lipid peroxidation process, chlorosis and in some instances tissue necrosis. Other antioxidant defences, including SOD and the ASC-GSH cycle enzymes also declined during the first days of infection, followed 
by an increase in response to the observed cellular damage that resulted from the development of the disease [94].

\subsubsection{Plant-ilarvirus interactions}

The ilarvirus prunus necrotic ringspot virus (PNRSV) is the causal agent of several diseases affecting most stone fruits [6]. This virus can infect immature apricot seeds including the embryo, and this infection provokes an oxidative stress, as monitored by increases in lipid peroxidation and an imbalance in antioxidant defences, including decreases in the ASC-GSH cycle enzymes and POX activity [4] (Table 1). This oxidative response resembles an HRlike response observed in some plant-virus interactions and can be regarded as a defence mechanism to inactivate PNRSV during seed formation or even during germination as observed by the low seed germination rate and the low PNRSV transmission rate by seeds in apricot trees [4].

\subsubsection{Plant-caulimovirus interactions}

The compatible infection of Arabidopsis plants with cauliflower mosaic virus (CaMV) activates the expression of genes related to three different defence response pathways, involving SA, JA/ ethylene and ROS as signalling molecules [97]. The authors described the systemic induction of the GST1 gene as well as $\mathrm{H}_{2} \mathrm{O}_{2}$ accumulation in tissues distant from the inoculation site. In addition, activation of the JA/ethylene defence signalling pathway was indicated by elevated expression of the marker gene PDF1.2. However, the mutations that interfere with ethylene signalling and perception (etr1-1 and ein2-1 mutants) abolished the systemic GST1 expression and $\mathrm{H}_{2} \mathrm{O}_{2}$ accumulation, although the inoculated leaves still showed high levels of $\mathrm{H}_{2} \mathrm{O}_{2}$ as assayed by DAB tissue staining. These results suggested that an intact ethylene-signalling pathway seems to be required for the propagation of the systemic ROS burst. The systemic signal that stimulates the ROS generation in distant leaves is unknown, but it seems that NADPH oxidase is the main, but not the exclusive, generator of ROS at sites distant from the inoculated leaves. In this sense, plants with mutations of individual NADPH oxidase genes (rbohD and rbohF) still showed some systemic $\mathrm{H}_{2} \mathrm{O}_{2}$ accumulation after CaMV infection. Different authors suggested a role for AOX in the regulation of ROS accumulation as well as in virus resistance mediated by ROS [see e.g. [45,53], discussed above]. In that regard, the inclusion of $50 \mu \mathrm{M}$ antimycin $\mathrm{A}$ in the virus inoculum, which stimulates mitochondrial electron transport through the AOX pathway, reduced the percentage of plants that develop systemic infection. In fact, Love et al. [97] have shown that stimulation of the AOX pathway by antimycin A induces resistance to CaMV. However, when the antimycin A treatment was carried out in a non-inoculated leaf, plants developed the same symptoms of systemic infection than control plants. These results suggested that the resistance to CaMV induced by antymicin A through activation of AOX and ROS accumulation acts locally rather than systemically [97].

\section{The interplay of plant oxidative stress and antioxidants is not sufficient to elicit resistance during compatible virus infections}

Evidence on the role of ROS and antioxidant metabolism in symptom development and pathogenesis in compatible plant-virus interactions is still rather scarce. However, during the past years valuable information, interesting new data have been published. Thus, it seems that during compatible virus infections typical senescence symptoms are induced in plants and, as in the senescence process, chloroplasts are the most damaged cell compartments. In fact, chloroplastic PSII, a potential site of
ROS generation is a main target of successful virus infections, suggesting that this organelle could be a source of oxidative stress during the progression of viral infection [see e.g. $[71,72,35,36,29,30]]$. Also, different authors point out that decreases in GSH can be responsible for virus elicited symptom development in susceptible plants [e.g. [4,36,94,157,158]]. In that regard, it is noteworthy to mention that treatments inducing increases in GSH and/or the redox state of glutathione can decrease the virus contents and/or the symptoms even during compatible virus infections [27,29,158].

During short-term responses to compatible virus infections the early induction of antioxidant defences can interfere with the ROS signalling needed to initiate resistance responses to the virus infection [see e.g. [7]]. This implies that a tight regulation of temporal and spatial ROS generation is necessary to activate plant defences against invading viruses. Thus, an early and efficient ROS accumulation and signalling would result in virus suppression even during compatible infections [11,66]. As regards the long-term responses to compatible virus infections, an imbalance in the antioxidative metabolism occurs that can be related to the damage produced by the infection. In fact, it seems that the magnitude of oxidative stress and the antioxidant response is associated with the severity of systemic symptoms during plant virus infections that are destined to be compatible.

\section{Conclusions}

The outcome and efficiency of defence reactions during plant-virus interactions may depend on the speed of the host response determined at least in part by an early and localized ROS accumulation at sites of virus infection. Accordingly, a very rapid, efficient host reaction (including fast, targeted ROS development) could result in early elimination of the virus without any oxidative stress and disease symptoms (extreme resistance). On the other hand, a somewhat delayed and less efficient host response allows a certain degree of virus replication and movement resulting in oxidative stress (localized death) of affected plant tissues before conferring a final arrest of pathogen invasion (HR).

An early and efficient ROS accumulation and signalling could result in at least a partial suppression of the invading virus even during compatible infections. However, during early, short-term responses to compatible virus infections the induction of antioxidant defences seems to interfere with ROS signalling needed to initiate resistance responses. Finally, during advanced stages of pathogenesis an imbalance in the antioxidative metabolism contributes to senescence-like symptoms in virus susceptible plant tissues. It seems that a delayed and/or failed attempt by the host to elicit virus resistance responses results in massively stressed plant tissues (e.g. virus-elicited systemic chlorotic/necrotic symptoms) and a partial or almost complete loss of control over pathogen invasion. Future research should determine the exact temporal and spatial location of the physiological "point of no return" of virus infections, after which they are destined to be compatible and the detailed role of ROS and antioxidants in these processes.

\section{Acknowledgements}

Research in the author's laboratories is supported by grants of the Hungarian Scientific Research Fund (K111995 and PD108455) and the Spanish Ministry of Economy and Competitiveness (Project INIA, RTA2013-00026-C03-00). PDV acknowledges the CSIC and the Spanish Ministry of Economy and Competitiveness for his 'Ramon y Cajal' research contract, cofinanced by FEDER funds. MJCM acknowledges the Spanish Ministry of Economy and Competitivenes for her 'Juan de la Cierva' research contract. The authors would like 
to thank Professor Zoltán Király for the critical review of the manuscript.

\section{References}

[1] T.E. Abbink, J.R. Peart, T.N. Mos, D.C. Baulcombe, J.F. Bol, H.J. Linthorst Silencing of a gene encoding a protein component of the oxygen-evolving complex of photosystem II enhances virus replication in plants, Virology 295 (2002) 307-319.

[2] E. Aguilar, D. Almendral, L. Allende, R. Pacheco, B.N. Chung, T. Canto, F. Tenllado, The P25 protein of Potato virus X (PVX) is the main pathogenicity determinant responsible for systemic necrosis in PVX-associated synergisms, J. Virol. 89 (2015) 2090-2103.

[3] A.C. Allan, M. Lapidot, J.N. Culver, R. Fluhr, An early tobacco mosaic virusinduced oxidative burst in tobacco indicates extracellular perception of the virus coat protein, Plant Physiol. 126 (2001) 97-108.

[4] K. Amari, P. Díaz-Vivancos, V. Pallás, M.A. Sánchez-Pina, J.A. Hernández Oxidative stress induction by Prunus necrotic ringspot virus infection in apricot seeds, Physiol. Plant 131 (2007) 302-310.

[5] S. Ando, A. Obinata, H. Takahashi, WRKY70 interacting with RCY1 disease resistance protein is required for resistance to Cucumber mosaic virus in Arabidopsis thaliana, Physiol. Mol. Plant Pathol. 85 (2014) 8-14.

[6] F. Aparicio, M.A. Sánchez-Pina, J.A. Sánchez-Navarro, V. Pallás, Location of Prunus necrotic ringspot Ilarvirus within pollen grains of infected nectarine trees: evidence from RT-PCR, dot-blot and in situ hybridisation, Eur. J. Plant Pathol. 105 (1999) 623-627.

[7] M.C. Arias, C. Luna, M. Rodriguez, S. Lenardon, E. Taleisnik, Sunflower chlorotic mottle virus in compatible interactions with sunflower: ROS generation and antioxidant response, Eur. J. Plant Pathol. 113 (2005) 223-232.

[8] K. Asada, The role of ascorbate peroxidase and monodehydroascorbate reductase in $\mathrm{H}_{2} \mathrm{O}_{2}$ scavenging in plants, in: J.G. Scandalios (Ed.), Oxidative Stress and Molecular Biology of Antioxidant Defences, Cold Spring Harbor Laboratory Press, Cold Spring Harbor, NY, 1997, pp. 715-735.

[9] K. Asada, The water-water cycle in chloroplasts: scavenging of active oxygen and dissippation of excess photons, Annu. Rev. Plant Physiol. Plant Mol. Biol. 50 (1999) 601-639.

[10] P.H. Atkinson, R.E.F. Matthews, On the origin of dark green tissue in tobacco leaves infected with tobacco mosaic virus, Virology 40 (1970) 344-356.

[11] R. Bacsó, Y.M. Hafez, Z. Király, L. Király, Inhibition of virus replication and symptom expression by reactive oxygen species in tobacco infected with Tobacco mosaic virus, Acta Phytopathol. Entomol. Hung. 46 (2011) 1-10.

[12] C.J. Baker, E.W. Orlandi, Active oxygen in plant pathogenesis, Annu. Rev. Phytopathol. 33 (1995) 299-321.

[13] M. Balasubramaniam, B.S. Kim, H.M. Hutchens-Williams, L.S. Loesch-Fries, The photosystem II oxygen-evolving complex protein PsbP interacts with the coat protein of Alfalfa mosaic virus and inhibits virus replication, Mol. Plant Microbe Interact. 27 (2014) 1107-1118.

[14] B. Barna, J. Fodor, M. Pogány, Z. Király, Role of reactive oxygen species and antioxidants in plant disease resistance, Pest Manag. Sci. 59 (2003) 459-464.

[15] A. Bendahmane, K. Kanyuka, D.C. Baulcombe, The Rx gene from potato controls separate virus resistance and cell death responses, Plant Cell 11 (1999) 781-791.

[16] T.M. Burch-Smith, M. Schiff, J.L. Caplan, J. Tsao, K. Czymmek, S.P. DineshKumar, A novel role for the TIR domain in association with pathogen-derived elicitors, PLoS Biol. 5 (2007) 501-514.

[17] G.P. Bolwell, P. Wojtaszek, Mechanisms for the generation of reactive oxygen species in defence - a broad perspective, Physiol. Mol. Plant Pathol. 51 (1997) 347-366.

[18] C. Bowler, M. Van Montagu, D. Inzé, Superoxide dismutase and stress tolerance, Annu. Rev. Plant Physiol. Plant Mol. Biol. 43 (1992) 83-116.

[19] M. Cambra, N. Capote, A. Myrta, G. Llacer, Plum pox virus and the estimated costs associated with sharka disease, Bull. OEPP EPPO Bull. 36 (2006) 202-204.

[20] J.L. Caplan, P. Mamillapalli, T.M. Burch-Smith, K. Czymmek, S.P. DineshKumar, Chloroplastic protein NRIP1 mediates innate immune receptor recognition of a viral effector, Cell 132 (2008) 449-462.

[21] L. Chaerle, M. Pineda, R. Romero-Aranda, D. Van Der Straeten, M. Baron, Robotized thermal and chlorophyll fluorescence imaging of pepper mild mottle virus infection in Nicotiana benthamiana, Plant Cell Physiol. 47 (2006) 1323-1336.

[22] S. Chamnongpol, H. Willekens, W. Moeder, C. Langebartels, H. Sandermann, M. Van Montagu, D. Inzé, W. Van Camp, Defense activation and enhanced pathogen tolerance induced by $\mathrm{H}_{2} \mathrm{O}_{2}$ in transgenic tobacco, Proc. Natl. Acad. Sci. U. S. A. 95 (1998) 5818-5823.

[23] Z. Chen, H. Silva, D.F. Klessig, Active oxygen species in the induction of plant systemic acquired resistance by salicylic acid, Science 262 (1993) 1883-1886.

[24] S. Chivasa, J.P. Carr, Cyanide restores $N$ gene-mediated resistance to tobacco mosaic virus in transgenic tobacco expressing salicylic acid hydroxylase, Plant Cell 10 (1998) 1489-1498.

[25] S. Chivasa, A.M. Murphy, M. Naylor, J.P. Carr, Salicylic acid interferes with tobacco mosaic virus replication via a novel salicylhydroxamic acid-sensitive mechanism, Plant Cell 9 (1997) 547-557.
[26] S.F. Clarke, P.L. Guy, D.J. Burritt, P.E. Jameson, Changes in the activities of antioxidant enzymes in response to virus infection and hormone treatment, Physiol. Plant 114 (2002) 157-164.

[27] M.J. Clemente-Moreno, P. Diaz-Vivancos, G. Barba-Espín, J.A. Hernández, Benzothiadiazole and L-2-oxothiazolidine-4-carboxylic acid reduced the severity of Sharka symptoms in pea leaves: effect on the antioxidative metabolism at subcellular level, Plant Biol. 12 (2010) 88-97.

[28] M.J. Clemente-Moreno, P. Diaz-Vivancos, A. Piqueras, J.A. Hernández, Plant growth stimulation in Prunus species plantlets by BTH or OTC treatments under in vitro conditions, J. Plant Physiol. 169 (2012) 1074-1083.

[29] M.J. Clemente-Moreno, P. Diaz-Vivancos, M. Rubio, N. Fernandez, J.A. Hernández, Chloroplast protection in plum pox virus-infected peach plants by L-2-oxo-4-thiazolidine-carboxylic acid treatments: effect in the proteome, Plant Cell Environ. 36 (2013) 640-654.

[30] M.J. Clemente-Moreno, J.A. Hernández, P. Diaz-Vivancos, Sharka: how do plants respond to plum pox virus infection? J. Exp. Bot. 66 (2015) 25-35.

[31] A.B. Cole, L. Király, K. Ross, J.E. Schoelz, Uncoupling resistance from cell death in the hypersensitive response of Nicotiana species to Cauliflower mosaic virus infection, Mol. Plant Microbe Interact. 14 (2001) 31-41.

[32] S.N. Covey, N.S. Al-Kaff, A. Langare, D.S. Turner, Plants combat infection by gene silencing, Nature 85 (1997) 780-781.

[33] M.B. Cooley, S. Pathirana, H.J. Wu, P. Kachroo, D.F. Klessig, Members of the Arabidopsis HRT/RPP8 family of resistance genes confer resistance to both viral and oomycete pathogens, Plant Cell 12 (2000) 663-676.

[34] J. Dat, S. Vandenabeele, E. Vranová, M. Van Montagu, D. Inzé, F. Van Breusegem, Dual action of the active oxygen species during plant stress responses, Cell. Mol. Life Sci. 57 (2000) 779-795.

[35] P. Diaz-Vivancos, M. Rubio, V. Mesonero, P.M. Periago, A. Ros Barceló, P. Martínez-Gómez, J.A. Hernández, The apoplastic antioxidant system in Prunus: response to plum pox virus, J. Exp. Bot. 57 (2006) 3813-3824.

[36] P. Diaz-Vivancos, M.J. Clemente-Moreno, M. Rubio, E. Olmos, J.A. Garcia, P. Martinez-Gomez, J.A. Hernandez, Alteration in the chloroplastic metabolism leads to ROS accumulation in pea plants in response to plum pox virus, J. Exp. Bot. 59 (2008) 2147-2160.

[37] S.P. Dinesh-Kumar, B.J. Baker, Alternatively spliced N resistance gene transcripts: their possible role in tobacco mosaic virus resistance, Proc. Natl. Acad. Sci. U. S. A. 97 (2000) 1908-1913.

[38] N. Doke, Y. Ohashi, Involvement of an $\mathrm{O}_{2}^{-}$generating system in the induction of necrotic lesions on tobacco leaves infected with tobacco mosaic virus, Physiol. Mol. Plant Pathol. 32 (1988) 163-175.

[39] S. Dorey, F. Baillieul, P. Saindrenan, B. Fritig, S. Kaufmann, Tobacco class I and II catalases are differentially expressed during elicitor-induced hypersensitive cell death and localized acquired resistance, Mol. Plant Microbe Interact. 11 (1998) 1102-1109.

[40] J. Draper, Salicylate, superoxide synthesis and cell suicide in plant defence, Trends Plant Sci. 2 (1997) 162-165

[41] U. Dubiella, H. Seybold, G. Durian, E. Komandera, R. Lassiga, C.P. Wittea, W.X. Schulzeb, T. Romeis, Calcium-dependent protein kinase/NADPH oxidase activation circuit is required for rapid defense signal propagation, Proc. Natl. Acad. Sci. U. S. A. 110 (2013) 8744-8749.

[42] J. Durner, D.F. Klessig Inhibition of ascorbate peroxidase by salicylic acid and 2,6-dichloroisonicotinic acid, two inducers of plant defense responses, Proc. Natl. Acad. Sci. U. S. A. 92 (1995) 113-126.

[43] J. Durner, D.F. Klessig, Salicylic acid is a modulator of tobacco and mammalian catalases, J. Biol. Chem. 271 (1996) 28492-28501.

[44] W.E. Durrant, X. Dong, Systemic acquired resistance, Annu. Rev. Phytopathol. 42 (2004) 185-209.

[45] C. Dutilleul, M. Garmier, G. Noctor, C. Mathieu, P. Chétrit, C.H. Foyer, R. de Paepe, Leaf mitochondria modulate whole cell redox homeostasis, set antioxidant capacity, and determine stress resistance through altered signaling and diurnal regulation, Plant Cell 15 (2003) 1212-1226.

[46] F.I.B. El-Moshaty, S.M. Pike, A.J. Novacky, O.P. Sehgal, Lipid peroxidation and superoxide production in cowpea (Vigna unguiculata) leaves infected with tobacco ringspot virus or southern bean mosaic-virus, Physiol. Mol. Plant Pathol. 43 (1993) 109-119.

[47] J. Fodor, G. Gullner, A.L. Adam, B. Barna, T. Kömíves, Z. Király, Local and systemic responses of antioxidants to tobacco mosaic virus infection and to salicylic acid in tobacco - role in systemic acquired resistance, Plant Physiol. 114 (1997) 1443-1451.

[48] J. Fodor, E. Hideg, A. Kecskés, Z. Király, In vivo detection of tobacco mosaic virus-induced local and systemic oxidative burst by electron paramagnetic resonance spectroscopy, Plant Cell Physiol, 42 (2001) 775-779.

[49] C.H. Foyer, G. Noctor, Ascorbate and glutathione: the heart of the redox hub, Plant Physiol. 155 (2011) 2-18.

[50] T. Gaffney, L. Friedrich, B. Vernooij, D. Negrotto, G. Nye, S. Uknes, E. Ward, H. Kessman, J. Ryals, Requirement of salicylic acid for the induction of systemic acquired resistance, Science 261 (1993) 754-756.

[51] F. Galiazzo, M.R. Ciriolo, M.T. Carri, P. Civitareale, L. Marcocci, F. Marmocchi, G. Rotilio, Activation and induction by copper of $\mathrm{Cu} / \mathrm{Zn}$ superoxide dismutase in Saccharomyces cerevisiae. Presence of an inactive proenzyme in anaerobic yeast, Eur. J. Biochem. 196 (1991) 545-549.

[52] A. Garcia-Marcos, R. Pacheco, J. Martinez, P. González-Jara, J.R. Díaz-Ruíz, F. Tenllado, Transcriptional changes and oxidative stress associated with the synergistic interaction between Potato virus $X$ and Potato virus $Y$ and their relationship with symptom expression, Mol. Plant Microbe Interact. 22 
(2009) 1431-1444

[53] A. Gilliland, D.P. Singh, J.M. Hayward, C.A. Moore, A.M. Murphy, C.J. York, J. Slator, J.P. Carr, Genetic modification of alternative respiration has differential effects on antimycin a-induced versus salicylic acid-induced resistance to Tobacco mosaic virus, Plant Physiol. 132 (2003) 1518-1528.

[54] S. Gilroy, N. Suzuki, G. Miller, W.G. Choi, M. Toyota, A.R. Devireddy, R. Mittler, A tidal wave of signals: calcium and ROS at the forefront of rapid systemic signaling, Trends Plant Sci. 19 (2014) 623-630.

[55] R.N. Goodman, Z. Király, K.R. Wood, The Biochemistry and Physiology of Plant Disease, University Missouri Press, Columbia, 1986.

[56] R.N. Goodman, A. Novacky, The Hypersensitive Reaction in Plants to Pathogens, APS Press, St. Paul, MN, 1994.

[57] J.T. Greenberg, N. Yao, The role and regulation of programmed cell death in plant-pathogen interactions, Cell Microbiol. 6 (2004) 201-211.

[58] J.J. Grant, G.J. Loake, Role of reactive oxygen intermediates and cognate redox signaling in disease resistance, Plant Physiol. 124 (2000) 21-29.

[59] M. Grant, C. Lamb, Systemic immunity, Curr. Opin. Plant Biol. 9 (2006) 414-420

[60] Y. Groemping, K. Rittinger, Activation and assembly of the NADPH oxidase: a structural perspective, Biochem. J. 386 (2005) 401-416.

[61] G. Gullner, J. Fodor, A. Józsa, R. Gáborjányi, Z. Király, Responses of the ascorbate-glutathione cycle to necrotic virus infections in tobacco, Phyton 37 (1997) 95-100.

[62] G. Gullner, I. Tóbiás, J. Fodor, T. Kömíves, Elevation of glutathione level and activation of glutathione-related enzymes affect virus infection in tobacco, Free Radic. Res. 31 (1999) S155-S161.

[63] Y.M. Hafez, R. Bacsó, Z. Király, A. Künstler, L. Király, Up-regulation of antioxidants in tobacco by low concentrations of $\mathrm{H}_{2} \mathrm{O}_{2}$ suppresses necrotic disease symptoms, Phytopathology 102 (2012) 848-856.

[64] Y.M. Hafez, Z. Király, Role of hydrogen peroxide in symptom expression of barley susceptible and resistant to powdery mildew, Acta Phytopathol Entomol. Hung. 38 (2003) 227-236.

[65] M.R. Hajimorad, J.H. Hill, Rsv1-mediated resistance against Soybean mosaic virus- $\mathrm{N}$ is hypersensitive response-independent at inoculation site, but has the potential to initiate a hypersensitive response-like mechanism, Mol Plant Microbe Interact. 14 (2001) 587-598.

[66] A. Hakmaoui, M.L. Pérez-Bueno, B. García-Fontana, D. Camejo, A. Jiménez F. Sevilla, M. Barón, Analysis of the antioxidant response of Nicotiana benthamiana to infection with two strains of Pepper mild mottle virus, J. Exp. Bot. 63 (2012) 5487-5496.

[67] B. Halliwell, J.M.C. Gutteridge, Free Radicals in Biology and Medicine, Oxford University Press Inc, New York, 1999.

[68] F. Hanquing, S. Kun, L. Mingquan, L. Hongyu, L. Xin, L. Yan, W. Yifeng, The expression, function and regulation of mitochondrial alternative oxidase under biotic stresses, Mol. Plant Pathol. 11 (2010) 429-440.

[69] N. Hatsugai, M. Kuroyanagi, K. Yamada, T. Meshi, S. Tsuda, M. Kondo, M. Nishimura, I. Hara-Nishimura, A plant vacuolar protease, VPE, mediates virus-induced hypersensitive cell death, Science 305 (2004) 855-858.

[70] J.A. Hernández, J.M. Talavera, P. Martínez-Gómez, F. Dicenta, F. Sevilla, Response of antioxidative enzymes to plum pox virus in two apricot cultivars, Physiol. Plant 111 (2001) 313-321.

[71] J.A. Hernández, M. Rubio, E. Olmos, A. Ros-Barceló, P. Martínez-Gómez Oxidative stress induced by long-term plum pox virus infection in peach (Prunus persica L. cv GF305), Physiol. Plant 122 (2004) 486-495.

[72] J.A. Hernández, P. Diaz-Vivancos, M. Rubio, E. Olmos, A. Ros-Barceló P. Martínez-Gómez, Long-term PPV infection produces an oxidative stress in a susceptible apricot cultivar but not in a resistant cultivar, Physiol. Plant 126 (2006) 140-152.

[73] A. Herrera-Vásquez, P. Salinas, L. Holuigue, Salicylic acid and reactive oxygen species interplay in the transcriptional control of defense genes expression, Front. Plant Sci. 6 (2015) 171

[74] E. Heyneke, N. Luschin-Ebengreuth, I. Krajcer, V. Wolkinger, M. Müller, B. Zechmann, Dynamic compartment specific changes in glutathione and ascorbate levels in Arabidopsis plants exposed to different light intensities, BMC Plant Biol. 13 (2013) 104-122.

[75] R. Hull, Matthews' Plant Virology, fourth ed., Academic Press, London, 2002.

[76] J. Inaba, B.M. Kim, H. Shimura, C. Masuta, Virus-induced necrosis is a consequence of direct protein-protein interaction between a viral RNAsilencing suppressor and a host catalase, Plant Physiol. 156 (2011) 2026-2036.

[77] A.M. Jones, J.L. Dangl, The plant immune system, Nature 444 (2006) $323-329$

[78] C.M. Jordan, R.J. Wakeman, J.E. Devay, Toxicity of free riboflavin and methionine riboflavin solutions to Phytophthora infestans and the reduction of potato late blight disease, Can. J. Microbiol. 38 (1992) 1108-1111.

[79] T. Keller, H.G. Damude, D. Werner, P. Doerner, R.A. Dixon, C. Lamb, A plant homolog of the neutrophil NADPH oxidase gp9 ${ }^{\text {phox }}$ subunit gene encodes a plasma membrane protein with $\mathrm{Ca}^{2+}$ binding motifs, Plant Cell 10 (1998) 255-266

[80] L. Király, Y.M. Hafez, J. Fodor, Z. Király, Suppression of tobacco mosaic virusinduced hypersensitive-type necrotisation in tobacco at high temperature is associated with down-regulation of NADPH oxidase and superoxide and stimulation of dehydroascorbate reductase J. Gen. Virol 89 (2008) 799-808.

[81] L. Király, A. Künstler, K. Höller, M. Fattinger, C. Juhász, M. Müller, G. Gullner, B. Zechmann, Sulfate supply influences compartment specific glutathione metabolism and confers enhanced resistance to Tobacco mosaic virus during a hypersensitive response, Plant Physiol. Biochem. 59 (2012) 44-54.

[82] Z. Király, H. El-Zahaby, A. Galal, S. Abdou, A. Ádám, B. Barna, Z. Klement, Effect of oxy free radicals on plant pathogenic bacteria and fungi and on some plant diseases, in: G. Mózsik, I. Emerit, J. Fehér, B. Matkovics, Vincze Á (Eds.), Oxygen Free Radicals and Scavengers in the Natural Sciences, Akadémiai Kiadó, Budapest, 1993, pp. 9-19.

[83] Z. Király, B. Barna, A. Kecskés, J. Fodor, Down-regulation of antioxidative capacity in a transgenic tobacco which fails to develop acquired resistance to necrotization caused by TMV, Free Radic. Res. 36 (2002) 981-991.

[84] Z. Klement, Hypersensitivity, in: M.S. Mount, G.H. Lacy (Eds.), Phytopathogenic Prokaryotes II, Academic Press, New York, 1982.

[85] P. Kogovsek, M. Pompe-Novak, S. Baebler, A. Rotter, L. Gow, K. Gruden, G.D. Foster, N. Boonham, M. Ravnikar, Aggressive and mild Potato virus Y isolates trigger different specific responses in susceptible potato plants, Plant Pathol. 59 (2010) 1121-1132.

[86] A. Künstler, Y.M. Hafez, L. Király, Transient suppression of a catalase and an alternative oxidase gene during virus-induced local lesion formation (hypersensitive response) is independent of the extent of leaf necrotization, Acta Phytopathol. Entomol. Hung. 42 (2007) 185-196.

[87] L.M. Lagrimini, S. Rothstein, Tissue specificity of tobacco peroxidase isozymes and their induction by wounding and tobacco mosaic virus infection, Plant Physiol. 84 (1987) 438-442.

[88] C. Laloi, M. Havaux, Key players of singlet oxygen-induced cell death in plants, Front. Plant Sci. 6 (2015) 39.

[89] C. Lamb, R.A. Dixon, The oxidative burst in plant disease resistance, Annu. Rev. Plant Physiol. Plant Mol. Biol. 48 (1997) 251-275.

[90] S. Lehmann, M. Serrano, F. L'Haridon, S.E. Tjamos, J.P. Metraux, Reactive oxygen species and plant resistance to fungal pathogens, Phytochemistry 112 (2015) 54-62.

[91] K. Lehto, M. Tikkanen, J.B. Hiriart, V. Paakkarinen, E.M. Aro, Depletion of the photosystem II core complex in mature tobacco leaves infected by the Flavum strain of Tobacco mosaic virus, Mol. Plant Microbe Interact. 16 (2003) $1135-1144$.

[92] J. Leon, M.A. Lawton, I. Raskin, Hydrogen peroxide stimulates salicylic acid biosynthesis in tobacco, Plant Physiol. 108 (1995) 1673-1678.

[93] A. Levine, R. Tenhaken, R. Dixon, C. Lamb, $\mathrm{H}_{2} \mathrm{O}_{2}$ from the oxidative burst orchestrates the plant hypersensitive disease resistance response, Cell 79 (1994) 583-593.

[94] Z. Li, D.J. Burritt, The influence of Cocksfoot mottle virus on antioxidant metabolism in the leaves of Dactylis glomerata L, Physiol. Mol. Plant Pathol. 62 (2003) 285-295.

[95] Y. Liao, M. Tian, H. Zhang, X. Li, Y. Wang, X. Xia, J. Zhou, Y. Zhou, J. Yu, K. Shi D.F. Klessig, Salicylic acid binding of mitochondrial alpha-ketoglutarate dehydrogenase E2 affects mitochondrial oxidative phosphorylation and electron transport chain components and plays a role in basal defense against Tobacco mosaic virus in tomato, New Phytol. 205 (2015) 1296-1307.

[96] Y. Liu, D. Ren, S. Pike, S. Pallardy, W. Gassmann, S. Zhang, Chloroplastgenerated reactive oxygen species are involved in hypersensitive responselike cell death mediated by a mitogen-activated protein kinase cascade, Plant J. 51 (2007) 941-954.

[97] A.J. Love, B.W. Yun, V. Laval, G.J. Loake, J.J. Milner, Cauliflower mosaic virus, a compatible pathogen of Arabidopsis, engages three distinct defensesignaling pathways and activates rapid systemic generation of reactive oxygen species, Plant Physiol. 139 (2005) 935-948.

[98] K.N. Madhusudhan, B.M. Srikanta, M.D. Shylaja, H.S. Prakash, H.S. Shetty Changes in antioxidant enzymes, hydrogen peroxide, salicylic acid and oxidative stress in compatible and incompatible host-tobamovirus interaction, J. Plant Interact. 4 (2009) 157-166.

[99] C.A. Manacorda, C. Mansilla, H.J. Debat, D. Zavallo, F. Sánchez, F. Ponz S. Asurmendi, Salicylic acid determines differential senescence produced by two Turnip mosaic virus strains involving reactive oxygen species and early transcriptomic changes, Mol. Plant Microbe Interact. 26 (2013) 1486-1498.

[100] M. Manohar, M. Tian, M. Moreau, S.W. Park, H.W. Choi, Z. Fei, G. Friso, M. Asif, P. Manosalva, C.C. von Dahl, K. Shi, S. Ma, S.P. Dinesh-Kumar, I. O'Doherty, F.C. Schroeder, K.J. van Wijk, D.F. Klessig, Identification of multiple salicylic acid-binding proteins using two high throughput screens, Front. Plant Sci. 5 (2015) 777.

[101] D. Marino, C. Dunand, A. Puppo, N. Pauly, A burst of plant NADPH oxidases, Trends Plant Sci. 17 (2012) 9-15.

[102] A. Mateo, D. Funck, P. Mühlenbock, B. Kular, P.M. Mullineaux, S. Karpinski, Controlled levels of salicylic acid are required for optimal photosynthesis and redox homeostasis, J. Exp. Bot. 57 (2006) 1795-1807.

[103] M.M. Mathioudakis, R.S.L. Veiga, T. Canto, V. Medina, D. Mossialos A.M. Makris, I. Livieratos, Pepino mosaic virus triple gene block protein 1 (TGBp1) interacts with and increases tomato catalase 1 activity to enhance virus accumulation, Mol. Plant Pathol. 14 (2013) 589-601.

[104] K. Maxwell, G.N. Johnson, Chlorophyll fluorescence: a practical guide, J. Exp. Bot. 51 (2000) 659-668.

[105] D.P. Maxwell, Y. Wang, L. McIntosh, The alternative oxidase lowers mitochondrial reactive oxygen production in plant cells, Proc. Natl. Acad. Sci. U. S. A. 96 (1999) 8271-8276.

[106] R. Mittler, Oxidative stress, antioxidants and stress tolerance, Trends Plant Sci. 7 (2002) 405-410.

[107] R. Mittler, X. Feng, M. Cohen, Post-transcriptional suppression of cytosolic 
ascorbate peroxidase expression during pathogen-induced programmed cell death in tobacco, Plant Cell 10 (1998) 461-473.

[108] R. Mittler, E. Lam, V. Shulaev, M. Cohen, Signals controlling the expression of cytosolic ascorbate peroxidase during pathogen-induced programmed cell death in tobacco, Plant Mol. Biol. 39 (1999) 1025-1035.

[109] W. Moeder, K. Yoshioka, D.F. Klessig, Involvement of the small GTPase Rac in the defense responses of tobacco to pathogens, Mol. Plant Microbe Interact. 18 (2005) 116-124.

[110] F. Morel, J. Doussiere, P.V. Vignais, The superoxide-generating oxidase of phagocytic cells. Physiological, molecular and pathological aspects, Eur. J. Biochem. 201 (1991) 523-546.

[111] I.M. Møller, Plant mitochondria and oxidative stress: electron transport, NADPH turnover, and metabolism of reactive oxygen species, Annu. Rev. Plant Physiol. Plant Mol. Biol. 52 (2001) 561-591.

[112] P. Montalbini, Enhanced uricase activity in tobacco mosaic virus infected tobacco leaves, Plant Sci. 74 (1991) 261-265.

[113] P. Montalbini, G. Della Torre, Evidence of a two-fold mechanism responsible for the inhibition by allopurinol of the hypersensitive response induced in tobacco by tobacco necrosis virus, Physiol. Mol. Plant Pathol. 48 (1996) 273-287.

[114] W.M. Nauseef, How human neutrophils kill and degrade microbes: an integrated view, Immunol. Rev. 219 (2007) 88-102.

[115] U. Neuenschwander, B. Vernooij, L. Friedrich, S. Uknes, H. Kessmann, J. Ryals, Is hydrogen peroxide a second messenger of salicylic acid in systemic acquired resistance? Plant J. 8 (1995) 227-233.

[116] G. Noctor, C.H. Foyer, Ascorbate and glutathione: keeping active oxygen under control, Annu. Rev. Plant Physiol. Plant Mol. Biol. 49 (1998) 249-279.

[117] J.A. O'Brien, A. Daudi, V.S. Butt, G.P. Bolwell, Reactive oxygen species and their role in plant defence and cell wall metabolism, Planta 236 (2012) 765-779.

[118] R. Pacheco, A. García-Marcos, A. Manzano, M. García de Lacoba, G. Camañes, P. García-Agustín, J.R. Díaz-Ruíz, F. Tenllado, Comparative analysis of transcriptomic and hormonal responses to compatible and incompatible plantvirus interactions that lead to cell death, Mol. Plant Microbe Interact. 25 (2012) 709-723.

[119] M.L. Perez-Bueno, J. Rahoutei, C. Sajnani, I. García-Luque, M. Barón, Proteomic analysis of the oxygen evolving complex of photosystem II under biotic stress: studies on Nicotiana benthamiana infected with tobamoviruses, Proteomic 4 (2004) 418-425.

[120] M.L. Perez-Bueno, M. Ciscato, M. van de Ven, I. García-Luque, R. Valcke, M. Barón, Imaging viral infection: studies on Nicotiana benthamiana plants infected with the pepper mild mottle tobamovirus, Photosynth. Res. 90 (2006) $111-123$.

[121] M. Pogány, J. Koehl, I. Heiser, E.F. Elstner, B. Barna, Juvenility of tobacco induced by cytokinin gene introduction decreases susceptibility to Tobacco necrosis virus and confers tolerance to oxidative stress, Physiol. Mol. Plant Pathol. 65 (2004) 39-47.

[122] J. Rahoutei, I. García-Luque, M. Barón, Inhibition of photosynthesis by viral infection: effect on PSII structure and function, Physiol. Plant 110 (2000) 286-292.

[123] M.V. Rao, G. Paliyath, D.P. Ormrod, D.P. Murr, C.B. Watkins, Influence of salicylic acid on $\mathrm{H}_{2} \mathrm{O}_{2}$ production, oxidative stress, and $\mathrm{H}_{2} \mathrm{O}_{2}$-metabolizing enzymes. Salicylic acid-mediated oxidative damage requires $\mathrm{H}_{2} \mathrm{O}_{2}$, Plant Physiol. 115 (1997) 137-149.

[124] F.G. Ratcliff, B.D. Harrison, D.C. Baulcombe, A similarity between viral defense and gene silencing in plants, Science 276 (1997) 1558-1560.

[125] S.L. Richards, K.A. Wilkins, S.M. Swarbreck, A.A. Anderson, N. Habib, A.G. Smith, M. McAinsh, J.M. Davies, The hydroxyl radical in plants: from seed to seed, J. Exp. Bot. 66 (2015) 37-46.

[126] M. Riedle-Bauer, Role of reactive oxygen species and antioxidant enzymes in systemic virus infections of plants, J. Phytopathol. 148 (2000) 297-302.

[127] C.A. Robson, G.C. Vanlerberghe, Transgenic plant cells lacking mitochondrial alternative oxidase have increased susceptibility to mitochondria-dependent and -independent pathways of programmed cell death, Plant Physiol. 129 (2002) 1908-1920.

[128] C. Rojas, K.S. Mysore, Glycolate oxidase is an alternative source for $\mathrm{H}_{2} \mathrm{O}_{2}$ production during plant defense responses and functions independently from NADPH oxidase, Plant Signal Behav. 7 (2012) 752-755.

[129] A.F. Ross, Systemic acquired resistance induced by localized virus infections in plants, Virology 14 (1961) 340-358.

[130] S. Rossetti, P.M. Bonatti, In situ histochemical monitoring of ozone- and TMV-induced reactive oxygen species in tobacco leaves, Plant Physiol. Biochem. 39 (2001) 433-442.

[131] M. Sagi, R. Fluhr, Superoxide production by plant homologues of the gp91 ${ }^{\text {phox }}$ NADPH oxidase. Modulation of activity by calcium and by tobacc mosaic virus infection, Plant Physiol. 126 (2001) 1281-1290.

[132] M. Sagi, R. Fluhr, Production of reactive oxygen species by plant NADPH oxidases, Plant Physiol. 141 (2006) 336-340.

[133] A.W. Segal, The function of the NADPH oxidase of phagocytes and its relationship to other NOXs in plants, invertebrates, and mammals, Int. J. Biochem. Cell Biol. 40 (2008) 604-618.

[134] K.-B.G. Scholthof, Tobacco mosaic virus: a model system for plant biology, Annu. Rev. Phytopathol. 42 (2004) 13-34.

[135] J. Shang, D.H. Xi, S. Yuan, F. Xu, M.Y. Xu, H.L. Qi, S.D. Wang, O.R. Huang, L. Wen, H.H. Lin, Difference of physiological characters in dark green islands and yellow leaf tissue of Cucumber mosaic virus (CMV)-infected Nicotiana tabacum leaves, Z. Naturforsch 65c (2010) 73-78.

[136] P. Sharma, A.B. Jha, R.S. Dubey, M. Pessarakli, Reactive oxygen species, oxidative damage, and antioxidative defense mechanism in plants under stressful conditions, J. Bot. 2012 (2012) 1-26.

[137] K. Shirasu, H. Nakajima, V.K. Rajasekhar, R.A. Dixon, C. Lamb, Salicylic acid potentiates an agonist-dependent gain control that amplifies pathogen signals in the activation of defense mechanisms, Plant Cell 9 (1997) 261-270.

[138] R.P. Singh, J.P.T. Valkonen, S.M. Gray, N. Boonham, R.A. Jones, C. Kerlan, J. Schubert, Discussion paper: the naming Potato virus $Y$ strains infecting potato, Arch. Virol. 153 (2008) 1-13.

[139] F. Solymosy, G.L. Farkas, Z. Király, Biochemical mechanism of lesion formation in virus-infected plant tissues, Nature 184 (1959) 706-707.

[140] X.S. Song, Y.J. Wang, W.H. Mao, K. Shi, Y.H. Zhou, Effect of cucumber mosaic virus infection on electron transport and antioxidant system in chloroplasts and mitochondria of cucumber and tomato leaves, Physiol. Plant 135 (2009) 246-257.

[141] S.H. Spoel, X. Dong, How do plants achieve immunity? Defence without specialized immune cells, Nat. Rev. Immunol. 12 (2012) 89-100.

[142] L. Sticher, B. Mauch-Mani, J.P. Métraux, Systemic acquired resistance, Annu. Rev. Phytopathol. 35 (1997) 235-270.

[143] N. Suzuki, G. Miller, J. Morales, V. Shulaev, M.A. Torres, R. Mittler, Respiratory burst oxidases: the engines of ROS signaling, Curr. Opin. Plant Biol. 14 (2011) 691-699.

[144] H. Takahashi, A. Kai, M. Yamashita, S. Ando, K.-T. Sekine, Y. Kanayama, H. Tomita, Cyclic nucleotide-gated ion channel-mediated cell death may not be critical for $R$ gene-conferred resistance to Cucumber mosaic virus in Arabidopsis thaliana, Physiol. Mol. Plant Pathol. 79 (2012) 40-48.

[145] A. Talarczyk, M. Krzymowska, W. Borucki, J. Hennig, Effect of yeast CTA1 gene expression on response of tobacco plants to tobacco mosaic virus infection, Plant Physiol. 129 (2002) 1032-1044.

[146] M.A. Torres, ROS in biotic interactions, Physiol. Plant 138 (2010) 414-429.

[147] M.A. Torres, J.D.G. Jones, J.L. Dangl, Reactive oxygen species signaling in response to pathogens, Plant Physiol. 141 (2006) 373-378.

[148] C. Triantaphylidès, M. Krischke, F.A. Hoeberichts, B. Ksas, G. Gresser, M. Havaux, F. Van Breusegem, M.J. Mueller, Singlet oxygen is the major reactive oxygen species involved in photooxidative damage to plants, Plant Physiol. 148 (2008) 960-968.

[149] E.W.T. Tsang, C. Bowler, D. Herouart, W. Van Camp, R. Villaroel, C. Genetello, M. Van Montagu, D. Inzé, Differential regulation of superoxide dismutases in plants exposed to environmental stress, Plant Cell 3 (1991) 783-792.

[150] H. Willekens, D. Inzé, M. Van Montagu, W. Van Camp, Catalases in plants, Mol. Breed. 1 (1995) 207-228.

[151] K.M. Wright, G.H. Duncan, K.S. Pradel, F. Carr, S. Wood, K.J. Oparka, S.S. Cruz, Analysis of the $N$ gene hypersensitive response induced by a fluorescently tagged tobacco mosaic virus, Plant Physiol. 123 (2000) 1375-1386.

[152] G. Wu, B.J. Shortt, E.B. Lawrence, J. Leon, K.C. Fitzsimmons, E.B. Levine, I. Raskin, D.M. Shah, Activation of host defense mechanisms by elevated production of $\mathrm{H}_{2} \mathrm{O}_{2}$ in transgenic plants, Plant Physiol. 115 (1997) 427-435.

[153] S.Y. Yi, S.H. Yu, D. Choi, Involvement of hydrogen peroxide in repression of catalase in TMV-infected resistant tobacco, Mol. Cells 15 (2003) 364-369.

[154] S.Y. Yi, S.H. Yu, D. Choi, Molecular cloning of a catalase cDNA from Nicotiand glutinosa L. and its repression by tobacco mosaic virus infection, Mol. Cells 9 (1999) 320-325.

[155] H. Yoda, Y. Yamaguchi, H. Sano, Induction of hypersensitive cell death by hydrogen peroxide produced through polyamine degradation in tobacco plants, Plant Physiol. 132 (2003) 1973-1981.

[156] B. Zechmann, Compartment-specific importance of glutathione during abiotic and biotic stress, Front. Plant Sci. 5 (2014). Article 566.

[157] B. Zechmann, G. Zellnig, M. Müller, Virus-induced changes in the subcellular distribution of glutathione precursors in Cucurbita pepo (L.), Plant Biol. 9 (2007a) 427-434

[158] B. Zechmann, G. Zellnig, A. Urbanek-Krajnc, M. Müller, Artificial elevation of glutathione affects symptom development in ZYMV-infected Cucurbita pepo L. plants, Arch. Virol. 157 (2007b) 747-762. 